\title{
Revision of the Genus Schizoretepora (Bryozoa, Cheilostomatida) from the Atlantic-Mediterranean region
}

\author{
Teresa MADURELL ${ }^{1, *}$, Mary SPENCER JONES ${ }^{2} \&$ Mikel ZABALA $^{3}$ \\ ${ }^{1}$ Institute of Marine Sciences (ICM-CSIC), Passeig Marítim de la Barceloneta 37-49, \\ 08003 Barcelona, Catalonia. \\ ${ }^{2}$ Department of Life Sciences, Natural History Museum, Cromwell Road, London SW7 5BD, UK. \\ ${ }^{3}$ Department d'Ecologia, Universitat de Barcelona (UB), Diagonal 645, 08028 Barcelona, Catalonia. \\ ${ }^{*}$ Corresponding author: tmadurell@icm.csic.es \\ ${ }^{2}$ Email: m.spencerjones@nhm.ac.uk \\ ${ }^{3}$ Email:mikozabala@montgri.eu

\footnotetext{
${ }^{1}$ urn:1sid:zoobank.org:author:AB9762AB-55CD-4642-B411-BDBE45CA2082

${ }^{2}$ urn:lsid:zoobank.org:author:0C8C2EBE-17E1-44DA-8FDB-DC35F615F95B

${ }^{3}$ urn:lsid:zoobank.org:author:7E533CE7-92CA-4A17-8E41-5C37188D0CDA
}

\begin{abstract}
We examined the type specimens and historical collections holding puzzling Atlantic and Mediterranean material belonging to the genus Schizoretepora Gregory, 1893. We performed a detailed study of the colonial characters and re-describe the resulting species and those that have rarely been found or have poor original descriptions. As a result of this revision, nine species are found in the northeast Atlantic and Mediterranean. Six of them are re-described and illustrated: S. aviculifera (Canu \& Bassler, 1930), S. calveti d'Hondt, 1975, S. imperati (Busk, 1884), S. sp. nov.? (= S. imperati sensu O’Donoghue \& de Watteville 1939) (in open nomenclature, specimen lacks ovicells), S. pungens (Canu \& Bassler, 1928) and S. solanderia (Risso, 1826). For S. dentata (Calvet, 1931), no material remains; furthermore, S. hassi Harmelin, Bitar \& Zibrowius, 2007 and S. serratimargo (Hincks, 1886) have recently been described and redescribed, respectively. This new arrangement attains a coherent geographical distribution: $S$. imperati seems restricted to the eastern Atlantic, $S$. dentata and $S$. calveti are deepwater species from Atlantic islands, $S$. pungens and $S$. aviculifera dwell on the African coasts of the Western Mediterranean, $S$. hassi and $S$. sp. nov.? (=S. imperati sensu O'Donogue \& de Wateville 1939 ) are confined to the Eastern Mediterranean, and S. solanderia and S. serratimargo live on the European coasts of the Mediterranean.
\end{abstract}

Keywords. Phidoloporidae, taxonomy.

Madurell T., Spencer-Jones M. \& Zabala M. 2019. Revision of the Genus Schizoretepora (Bryozoa, Cheilostomatida) from the Atlantic-Mediterranean region. European Journal of Taxonomy 536: 1-33. https://doi.org/10.5852/ejt.2019.536

\section{Introduction}

The genus Schizoretepora Gregory, 1893 belongs to the species-rich cheilostome (bryozoan) family Phidoloporidae Gabb \& Horn, 1862, often referred to as lace corals. The genus was established by 
Gregory (1893) for Schizoretepora tessellata (Hincks, 1878) from SW Australia and Schizellozoon Canu \& Bassler, 1917 was later synonymized with it. The genus Schizoretepora is characterized by erect colonies either fenestrate or ramose, bilaminated (i.e., S. tessellata, S. serratimargo (Hincks, 1886)), by having oral spines, a primary orifice provided with a sinus and lacking proximal oral avicularia, with large frontal avicularia and large ovicells, ornate with a broad longitudinal central fissure and without lip (e.g., Canu \& Bassler 1917; Gautier 1962; Zabala \& Maluquer 1988; Harmelin et al. 2007).

To date, the genus Schizoretepora comprises 15 accepted species (according to WORMS http://www.marinespecies.org/ and IBA http://www.bryozoa.net/), of which 10 are supposed to dwell in the Mediterranean and northeast Atlantic regions. Only five of them have a recognized distribution along the Mediterranean (Rosso \& Di Martino 2016: S. hassi Harmelin, Bitar \& Zibrowius, 2007; S. imperati (Busk, 1884); S. longisetae (Canu \& Bassler, 1928); S. solanderia (Risso, 1826); and $S$. serratimargo). Most of the records for these species come from the western basin, except $S$. hassi, a recently described species which seems to be either steno-endemic in the Eastern Mediterranean or an Erythraean alien species (Harmelin et al. 2007). The remaining five species have never been recorded since their description (i.e., S. aviculifera (Canu \& Bassler, 1930) and S. granulosa (Canu \& Bassler, 1930) from the Mediterranean Tunisian coast; and S. calveti d'Hondt, 1975, S. dentata (Calvet, 1931) and S. pungens (Canu \& Bassler, 1925) from the Atlantic area).

Even if the status of some species of this genus is now undisputed (i.e., S. solanderia, S. serratimargo and $S$. hassi), the current taxonomic limits among the others is far from clear. The zooidal morphology in this genus is complex, subject to deep ontogenetic changes across the colony, and thus they look extraordinarily variable (e.g., $S$. hassi and $S$. tessellata). There has been no monographic account of the genus, and most of the species have not been clearly figured, nor re-described. In fact, most descriptions date from the late $1800 \mathrm{~s}$ and early 1900s. Some of those original descriptions and illustrations lack detail and are inadequate to present standards. All combined, this makes diagnoses confusing and the current taxonomic inconsistencies lead to misidentification.

\section{The 'S. imperati-group' problem}

Most of the puzzle turns around $S$. imperati and the species close to it, which we choose to call the 'imperati-group': S. aviculifera, S. granulosa, S. imperati, S. longisetae and S. pungens.

Schizoretepora imperati was first described by Busk from Challenger material collected along the Cape Verde coast (E Atlantic) (Busk 1884). Afterwards, it was also cited from Oran (Mediterranean) by Waters (1925), and from Tunisia (Mediterranean) and Eastern Atlantic coasts by Canu \& Bassler $(1928,1930)$. In fact, it was Canu \& Bassler $(1925,1928,1930)$ who introduced a great deal of uncertainty when they described four new species after the surveys performed along the Atlantic coast of Morocco (Dragages Vanneau) and the Mediterranean Tunisian coast (material collected by P. Pallary in 1904). All the descriptions were supported by pictures taken with an optical microscope, a novelty at that time, thought to improve the accuracy of the descriptions. These photographs, however, lack the details illustrated in drawings. In any case, the descriptions of the four new species (S. aviculifera, S. granulosa, S. longisetae and S. pungens) were rather overlapping and Canu \& Bassler (1925, 1928 and 1930) already pointed out the similarities between all of them. Later authors have struggled with these species, to the extent that two of them ( $S$. aviculifera and $S$. pungens) have been uncertainly synonymized with $S$. imperati (Barroso 1935; Gautier 1962; d'Hondt 1978; Zabala 1986; Zabala \& Maluquer 1988; d'Hondt \& Ben Ismail 2008).

The goal of this work is thus threefold. Firstly to clarify the imperati-group problem in order to solve the present taxonomic puzzle; secondly to redescribe the resulting Atlanto-Mediterranean species, as well as those that have rarely been found and are poorly described; and thirdly to build a key for all the species of the genus supposedly inhabiting the Atlantic-Mediterranean region. To this purpose, we re- 
examine the original type specimens and the historical collections holding Atlantic and Mediterranean material, and perform a morphometric study of the colonies, based on photographs using scanning electron microscopy (SEM).

\section{Material and methods}

\section{Museum collections}

The studied material comprises specimens from the bryozoan collections in the Department of Life Sciences of the Natural History Museum, London (NHMUK), the Musée océanographique de Monaco (MOM) and the Departments of Zoology and Paleontology of the Musée national d'Histoire naturelle in Paris (MNHN), as well as additional own material from the western Mediterranean, which is housed in the Museum of Natural Sciences in Barcelona (MZB).

We followed the bryozoan systematic classification in WoRMS (World Register of Marine Species) compiled by Bock \& Gordon (2017).

\section{The imperati-group problem}

\section{Metric analysis}

All specimens were photographed, uncoated, with either a Quanta 200 FEI, XTE 325/D8395 SEM, a LEO VP-1455 SEM or a HITACHI SU3500 SEM, using the backscattered electron (BSD) mode, under variable pressure. Some of our own material was treated with diluted domestic bleach on selected specimens.

All measurements were made on SEM pictures using the image software ImageJ (Schneider et al. 2012) and are given in microns $(\mu \mathrm{m})$. The orifice in certain species is obscured by the operculum; therefore, it is termed 'aperture' to distinguish it from the primary orifice in autozooids. Measured characters are identified by the following acronyms and abbreviations:

$\begin{array}{ll}\mathrm{AAL} & =\text { adventitious avicularium length } \\ \mathrm{AAW} & =\text { adventitious avicularium width } \\ \mathrm{AbAL} & =\text { abfrontal avicularium length } \\ \mathrm{AbAW} & =\text { abfrontal avicularium width } \\ \mathrm{AbVL} & =\text { abfrontal vicarious avicularia length } \\ \mathrm{AbVW} & =\text { abfrontal vicarious avicularia width } \\ \mathrm{ApL} & =\text { aperture length in zooecia with operculum } \\ \mathrm{ApW} & =\text { aperture width in zooecia with operculum } \\ \mathrm{AzL} & =\text { autozooid length } \\ \mathrm{AzW} & =\text { autozooid width } \\ \mathrm{FL} & =\text { fenestrulae length } \\ \mathrm{FW} & =\text { fenestrulae width } \\ \mathrm{Np} & =\text { number of frontal pores } \\ \mathrm{Np} A \mathrm{Ab} & =\text { number of abfrontal pores } \\ \mathrm{Ns} & =\text { number of oral spines } \\ \mathrm{Nz} & =\text { number of zooids per branch } \\ \mathrm{OL} & =\text { primary orifice length } \\ \mathrm{OVL} & =\text { ovicell length } \\ \mathrm{OVW} & =\text { ovicell width } \\ \mathrm{OW} & =\text { primary orifice width } \\ \mathrm{TW} & =\text { trabeculae width } \\ \mathrm{VAL} & =\text { giant avicularium length } \\ \mathrm{VAW} & =\text { giant avicularium width }\end{array}$




\section{Qualitative analysis}

Some of the most common discriminant characters for the determination of bryozoans are useless in the present analysis. Thus, all the studied species share the presence and number of spines, shape of the aperture (condyles, sinus, denticles), presence of giant frontal avicularia and ovicell shape. By contrast, some qualitative characters show enough intra-colonial stability and inter-colonial variability to discriminate between species. In order to make a clear splitting of these qualitative characters we used the following categorical attributes:

- abfrontal oval adventitious avicularia: absent, rare, frequent

- abfrontal surface: smooth, rugose, tuberculate

- abfrontal triangular adventitious avicularia: absent, rare, frequent

- abfrontal vicarious avicularia: absent, rare, frequent

- adventitious avicularia: absent, rare, frequent

- frequency of frontal pores: based on average number of pores

- frontal shield surface: smooth, finely rugose, rugose

- ovicell: longer than broad, broader than long

- peristome shape: rounded, triangular

We also recorded both the conservation status (alive/dead) and the developmental stage (young/old) of the fragment of colonies under study, in view of the suspicion that ontogenetic development and conservation have played a role in previous misidentifications.

\section{Multivariate statistical analysis}

Multivariate statistical analyses were performed on both qualitative and metric characters to test similarities between colonies. All analyses for metric and non-metric characters were carried out using PRIMER 6 statistical software (Clarke \& Gorley 2006).

Hierarchical cluster analysis was performed on qualitative non-metric characters after they had been normalized. The similarity matrix was calculated on Euclidean distance. Metric variables were transformed to $\log (\mathrm{X}+1)$. Due to the lack of replicates for some characters, five to ten autozooids from each colony were chosen randomly to incorporate intracolonial variability. The Bray-Curtis similarity index was then calculated between each pair of colonies for all these measures. An analysis

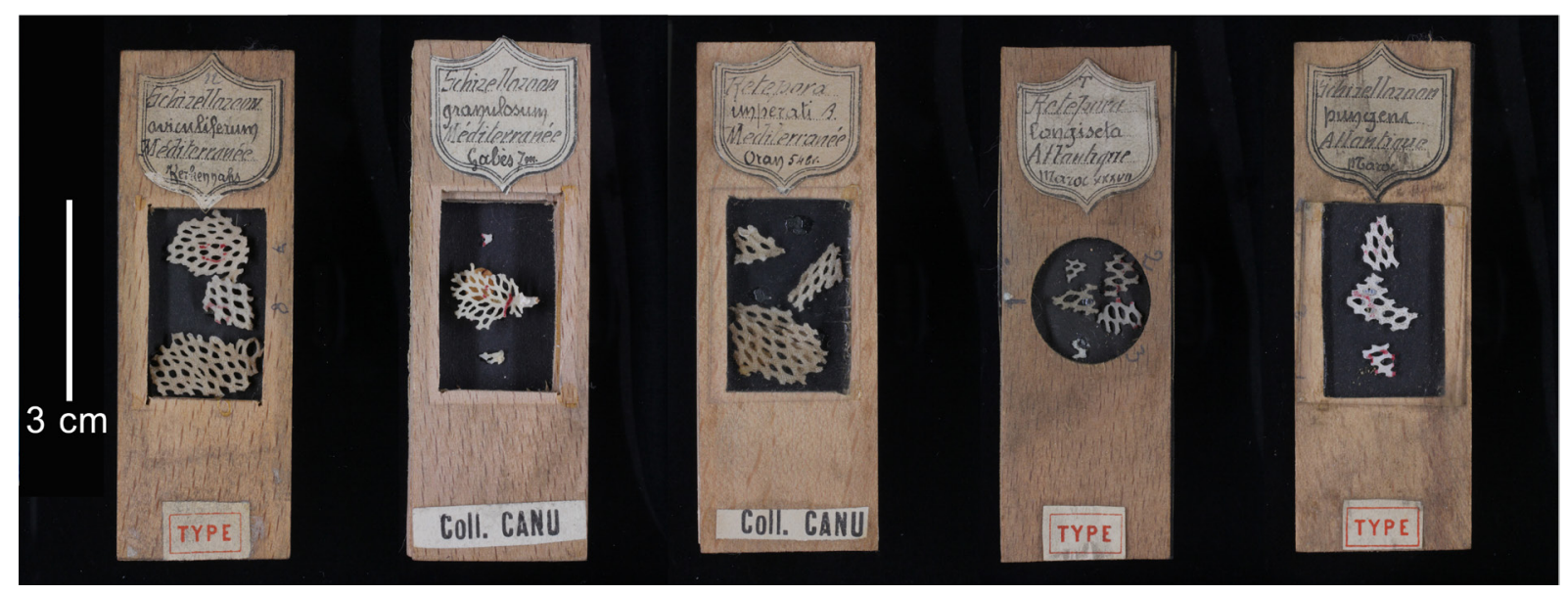

Fig. 1. Preparations of the 'imperati-group': Schizoretepora aviculifera (Canu \& Bassler, 1930) (MNHN-IB-2014-24), S. granulosa (Canu \& Bassler, 1930) (MNHN-IB-2014-21), S. imperati (Busk, 1884) (MNHN-IB-2014-29), S. longisetae (Canu \& Bassler, 1928) (MNHN-IB-2014-19) and S. pungens (Canu \& Bassler, 1925) (MNHN-IB-2014-20). Specimens located at the Departments of Zoology and Paleontology of the MNHN in Paris. 
of similarities (ANOSIM) was also performed to statistically test the null hypothesis that there are no overall differences between species.

This study comprises all the museum specimens originally labelled as pertaining to one of the species grouped in the imperati-group: S. aviculifera, S. granulosa, S. imperati, S. longisetae and S. pungens (Fig. 1). We also include $S$. hassi in the morphometric analysis because of its unexpected similarity with S. aviculifera.

\section{Results}

\section{The imperati-group problem}

\section{Qualitative analysis}

The results of the comparison of qualitative attributes are summarized in Fig. 2. The lack of frontal adventitious avicularia separates the true $S$. imperati (the original type specimens from Busk 1884) from the rest of the ' $S$. imperati' species. The presence of oval abfrontal avicularia clustered all the Mediterranean and Atlanto-Moroccan colonies originally labeled as S. imperati, S. pungens and S. longisetae. The triangular abfrontal avicularia are characteristic of $S$. imperati Busk, S. 'imperati' sensu O'Donoghue \& de Watteville 1939 and S. aviculifera. A larger number of pores and a rugose frontal surface discriminates S. aviculifera and S. granulosa.

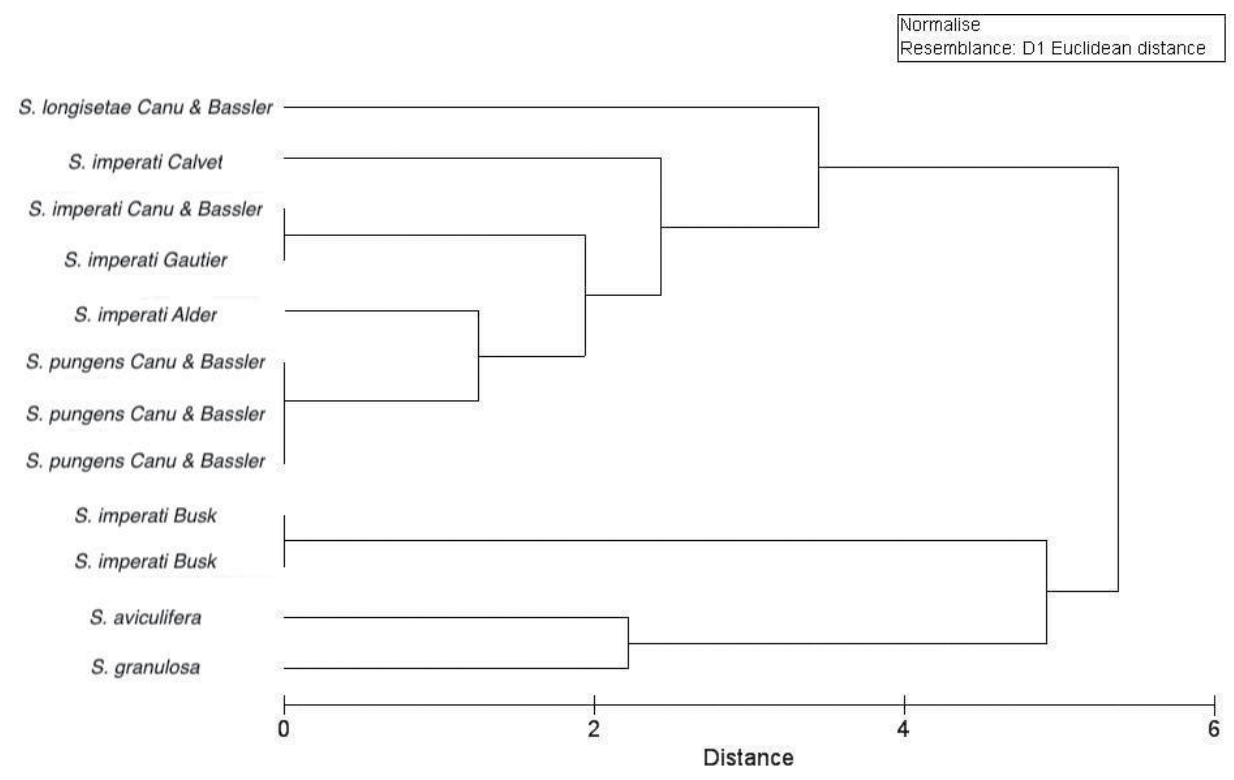

Fig. 2. Dendrogram on qualitative characters (frontal shield surface; frequency of frontal pores; peristome shape; frequency of adventitious avicularia, abfrontal vicarious avicularia, abfrontal oval adventitious avicularia and abfrontal triangular adventitious avicularia; abfrontal surface; ovicell shape) of the species that constitute the imperati-group: S. aviculifera (Canu \& Bassler, 1930), S. granulosa (Canu \& Bassler, 1930), S. imperati (Busk, 1884), S. imperati from other authors, S. longisetae (Canu \& Bassler, 1928) and S. pungens (Canu \& Bassler, 1925). Schizoretepora “imperati” sensu O’Donoghue \& de Watteville 1939 has been excluded from the analysis because it lacks ovicells. 


\section{Morphometric analysis}

Metric attributes (Fig. 3) confirmed the segregation shown in the qualitative analysis. The first two PCA axes explain $73.7 \%$ of the variability. From the metrical point of view, the first species to separate is $S$. hassi, which is larger for all measurements. The second detached group corresponds to the smallest specimens that noticeably groups all the Mediterranean and Atlanto-Moroccan specimens previously labelled as $S$. imperati, $S$. longisetae and $S$. pungens. The third group of species is more disperse and encompasses $S$. imperati (Busk, 1884), and S. 'imperati' sensu O'Donoghue \& de Watteville 1939. The fourth most scattered group encloses $S$. aviculifera and $S$. granulosa, the specimens showing greater interspecific variability. The most discriminating character is the zooidal size (i.e., AzL), which separates the western Mediterranean specimens of the imperati group (smaller species) from S. hassi, S. imperati Busk and S. imperati sensu O'Donoghue \& de Watteville,1939 (larger species). The first principal component is strongly and positively correlated with the AzL, and secondly with avicularian size (i.e., AbAL and VAL). AbAL and VAW also grow with increasing values of the first principal component, suggesting that these two criteria vary together. The second component is related to the AzW and is the most important factor to discriminate between $S$. aviculifera and $S$. hassi.

In summary, the present analysis resolves that the imperati group must be partitioned into four different species. The true S. imperati of Busk (1884) is a different species from the Mediterranean material, and at present it is only known from the Cape Verde Islands in the Atlantic. All the specimens previously assigned to $S$. imperati from the Mediterranean belong to the same species, described by Canu \& Bassler as two separate species: $S$. longisetae and S. pungens. The latter name has priority. On the other hand, S. aviculifera and S. granulosa from Canu \& Bassler are the same species. There is a striking similarity of S. aviculifera with the recently created S. hassi (Harmelin et al. 2007). Finally, the Egyptian specimen of S. 'imperati' sensu O'Donoghue \& de Watteville 1939 seems to separate as a different species. The existence of a sole specimen lacking ovicells, however, suggests that a complete description must wait for more material to be collected.

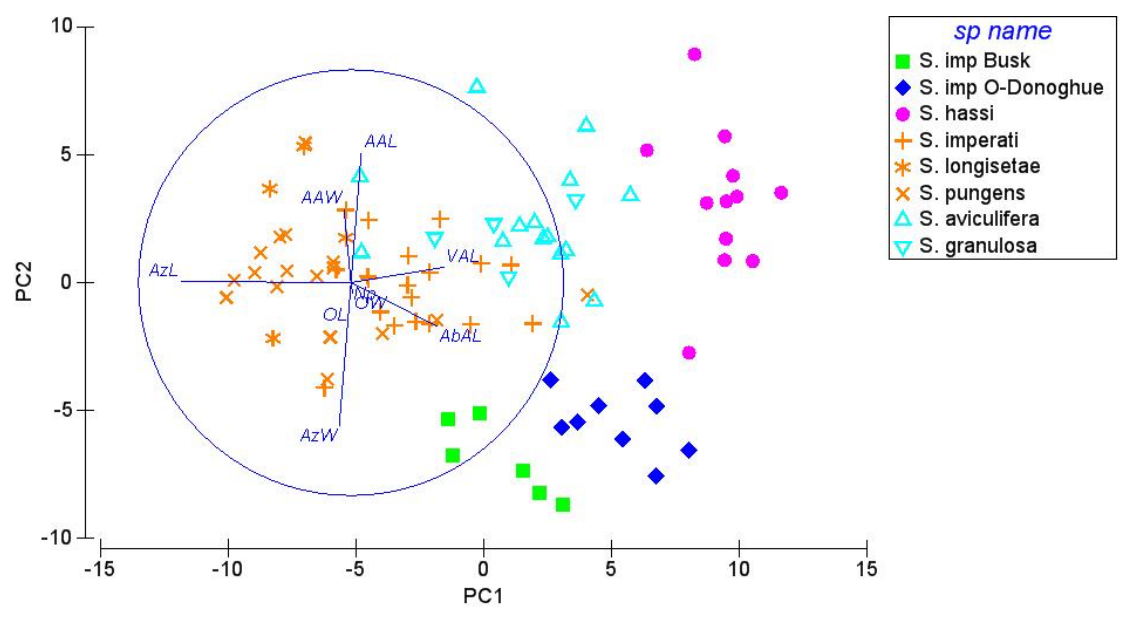

Fig. 3. Principal component analysis (PCA) biplot based on metric characters of the species Schizoretepora aviculifera (Canu \& Bassler, 1930), S. granulosa (Canu \& Bassler, 1930), S. hassi Harmelin, Bitar \& Zibrowius, 2007, S. imperati (Busk, 1884), S. imperati sensu O'Donoghue \& de Watteville 1939, S. imperati of other authors, S. longisetae (Canu \& Bassler, 1928) and S. pungens (Canu \& Bassler, 1925) . 


\section{Key to Schizoretepora species from the Atlanto-Mediterranean region}

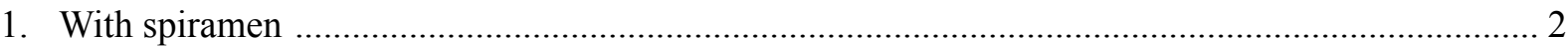

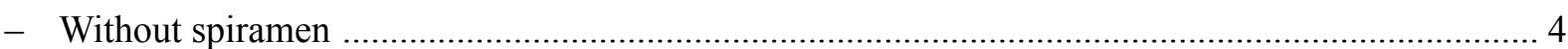

2. Branches uniseriate; giant frontal avicularia projecting perpendicular to the sides, longer than the branch width

- Branches bi- or pluriseriate; frontal avicularia shorter than the branch width 3

3. Branches bi- or triseriate; distal ends of the large bilobated peristome converging to form a large circular spiramen calveti d'Hondt, 1975.

- Branches quadri- or pluriseriate; distal ends of the large bilobated peristome converging to form a drop-shaped spiramen solanderia (Risso, 1826)

4. Erect vinculariform (or reteporiform) colonies 5

- Erect laminate colonies serratimargo (Hincks, 1886)

5. Without frontal adventitious avicularia 6

- With frontal adventitious avicularia ....

6. Abfrontal slightly rugose but not tuberculate; frontal slightly rugose (not tuberculate), with low number of pores (2-4); zooids longer (average AzL > $470 \mathrm{~mm}$; min AzL: $320 \mathrm{~mm}$ )

imperati (Busk, 1884)

- Abfrontal strongly rugose, tuberculate; frontal tuberculate, with higher number of pores (2-5); zooids shorter (average AzL $<350 \mathrm{~mm}$; max AzW: $450 \mathrm{~mm}$ )

sp. nov.? (= S. imperati sensu O’Donoghue \& de Watteville 1939)

7. Frontal adventitious avicularia of two types (oval and almond-like); frontal slightly rugose, with few areolae (2-3); abfrontal smooth or slightly rugose, with adventitious oval avicularia and rare triangular avicularia pungens (Canu \& Bassler, 1925)

- Frontal adventitious avicularia only almond-like with acute end; frontal rugose or nodular, with larger number of areolae (4-5); abfrontal rugose, with abundant triangular adventitious avicularia but lacking oval adventitious avicularia

8. Colonies always fenestrate (reteporiform); with large number of abfrontal wide triangular adventitious avicularia; zooids narrower (average AzW < $260 \mathrm{~mm}$; max AzL: $380 \mathrm{~mm}$ )

aviculifera (Canu \& Bassler, 1930)

- Colonies branched, but poorly fenestrated (vinculariform); with few sparse thin abfrontal triangular avicularia; zooids wider (average AzW > $330 \mathrm{~mm}$; min AzL: $240 \mathrm{~mm}$

hassi Harmelin, Bitar \& Zibrowius, 2007

\section{Systematic account}

In this section, we fully re-describe the species found in the northeast Atlantic and Mediterranean Sea, with the exception of $S$. dentata, the type specimen of which, housed at MOM, is badly damaged; and of $S$. hassi and S. serratimargo, which were recently described and redescribed respectively (Harmelin et al. 2007; Reverter \& Fernández-Pulperio 2007), as Schizotheca serratimargo and are not controversial. 
Phylum Bryozoa Ehrenberg, 1831

Class Gymnolaemata Allman, 1856

Order Cheilostomatida Busk, 1852

Suborder Flustrina Smitt, 1868

Superfamily Celleporoidea Johnston, 1838

Family Phidoloporidae Gabb \& Horn, 1862

Genus Schizoretepora Gregory, 1893

\section{Type species}

Retepora tessellata Hincks, 1878.

Schizoretepora calveti d'Hondt, 1975

Fig. 4, Table 1

Schizoretepora calveti d'Hondt, 1975: 581.

Schizellozoon tesselatum - Calvet 1931: 108, pl. 2, fig. 32.

\section{Material examined}

Lectotype (designated here)

AÇORES - 3 fragments; $36^{\circ} 54.0 \mathrm{~N}, 25^{\circ} 09.5 \mathrm{~W} ; 665-712 \mathrm{~m}$; on gravel and pebbles; R/V Jean-Charcot Biaçores 1971 exped., st. 230; MNHN-IB-2008-7565.

\section{Description}

Colony erect and delicate, arborescent, dichotomously branched, vinculariform (never fenestrate) (Fig. 4A). Frontal faces bearing autozooids, abfrontal faces consisting of sheets of kenozooids. Branches thin, with two alternate series of autozooids.

Autozooids longer than wide, separated by distinct sutures. Branches biseriate, arranged in two alternating series of zooids (young apical branches), or triseriate quincuncially arranged (older basal branches). Frontal shield surface rippled, with meandering reliefs (Fig. 4A).

Primary orifice obscured by a tubular peristome, only its proximal side being visible through the spiramen. Proximal border provided with sharp, flat condyles drawing a U-shaped shallow sinus; distal border not observed (Fig. 4B).

Peristome well-developed. In young zooids it grows as two lobes, slightly widening at its free edge, embodying 6-8 spiniform processes on each side and converging at the anterior end (Fig. 4B, E), but remaining cut by large circular spiramen, shaped like ace of spades (Fig. 4A-B, E); in older zooids, distal end of lobes appear just denticulate and spiramen disappears (Fig. 4D).

One to three very large acute avicularia (usually paired), placed over large cystid in middle of frontal shield (when single) on both sides of aperture (when paired), mostly directed proximally, but sometimes distally (Fig. 4E). Rostrum acute and distally hooked, with stout bar without columella. One round pore on each side of cystid, 2 to 4 for entire frontal.

The ovicell in the type material (incompletely developed?) is hyperstomial, resting distally on adjacent zooid frontal shield, longer than wide; cut by large frontal fissure, broader at its distal end, smooth and imperforate, non-cleithral (Fig. 4A, E). 
Abfrontal side consisting of sheets of irregular kenozooids separated by raised sutures; surface rippled, with numerous avicularia of two types: one similar to those on frontal, large and acute, 1-3 per kenozooid, becoming occluded by secondary calcification; and small elliptical avicularia rarely present (might be the anterior part of the large avicularia from which distal end has been occluded by calcification) (Fig. 4F).

Schizoretepora calveti is a deep-water species that has only been reported from the Azores archipelago, 599-712 m deep.
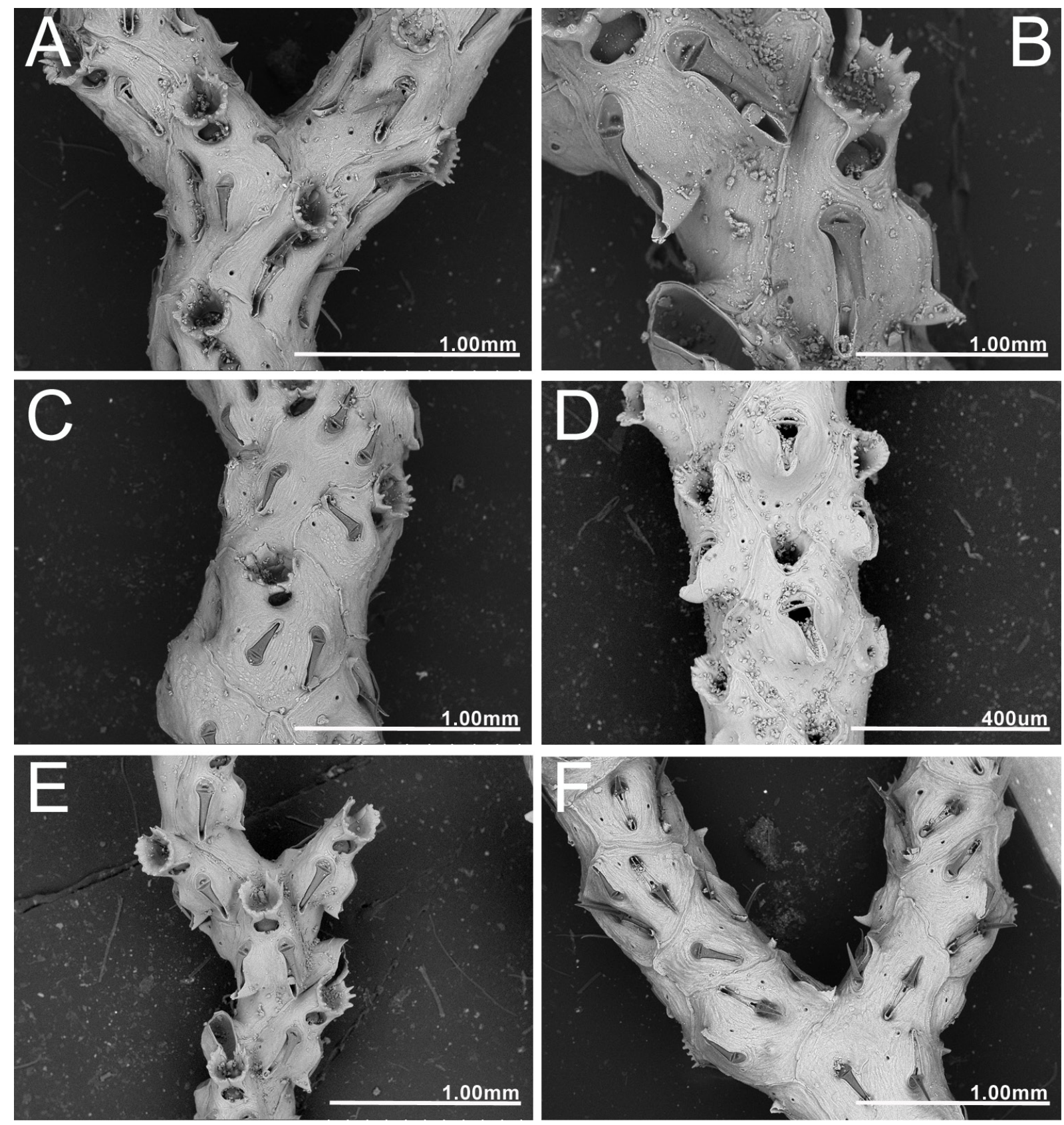

Fig. 4. Schizoretepora calveti d'Hondt, 1975, lectotype (MNHN-IB-2008-7565). A. Colony view. B. Detail of aperture and avicularia. C. Young autozooids and avicularia in frontal view. D. Older autozooids and avicularia in frontal view. E. Ovicellate zooids. F. Abfrontal view with avicularia. 
Table 1. Measurements of Schizoretepora calveti d'Hondt, 1975.

\begin{tabular}{cccccc}
\hline & N & MEAN & SD & MIN & MAX \\
\hline AzL & 18 & 970 & 84 & 750 & 1097 \\
AzW & 18 & 568 & 116 & 396 & 746 \\
ApL & 22 & 210 & 36 & 160 & 289 \\
ApW & 22 & 180 & 30 & 124 & 242 \\
VAL & 40 & 329 & 53 & 227 & 440 \\
VAW & 40 & 117 & 35 & 76 & 219 \\
AbAL & 2 & 121 & 5 & 118 & 125 \\
AbAW & 2 & 66 & 7 & 61 & 71 \\
AbVL & 21 & 276 & 22 & 228 & 309 \\
AbVW & 21 & 87 & 9 & 71 & 106 \\
OVL & 4 & 269 & 14 & 258 & 289 \\
OVW & 4 & 223 & 19 & 197 & 241 \\
Np & 12 & 4 & 1 & 2 & 4 \\
Np_Ab & 10 & 3 & 1 & 2 & 5 \\
\hline
\end{tabular}

\section{Remarks}

This species was first figured by Calvet (1931) and considered as a variety of Schizellozoon tessellatum. D'Hondt (1975) noticed the differences in the material dredged by the Jean-Charcot during the Biaçores mission and that figured by Calvet (1931). After comparison with the type material sent by the British Museum he erected a new species: Schizoretepora calveti. D'Hondt (1975) did not designate a lectotype from his material; therefore, we formally designate here as type material the specimen MNHNIB-2008-7565.

Looking at the abfrontal avicularia, this species resembles the Mediterranean species Reteporella pelecanus (López de la Cuadra \& García Gómez, 2001). However, the latter species is a true Reteporella Busk, 1884, possessing frontal labial avicularia and ovicells with an elongate median fissure not observed in the genus Schizoretepora. Nonetheless, the aspect of the frontal side with the circular spiramen and long peristome makes $S$. calveti unmistakable.

Schizoretepora solanderia (Risso, 1826)

Fig. 5, Table 2

Retepora solanderia Risso, 1826: 344.

Retepora solanderia - Waters 1895: 264, pl. VI, figs 1-4. - Calvet 1902: 35, pl. 2, figs 5-8. Schizoretepora solanderia - Gautier 1962: 237. — Zabala \& Maluquer 1988: 399, figs 395-396. — Rosso 2003: 17, fig.1. — Rosso et al. 2010: 604.

\section{Material examined}

TUNISIA • 10 fragments; Tabarka, st. 19; 86 m deep; Waters leg.; coll. Jullien 152; MNHN-IB-2008-2947.

SPAIN • 2 colonies; Menorca Channel, st. 72; 115 m deep; Indemares 6 exped.; MZB 2014-1486 • 3 colonies; Menorca Channel, st. 89; 140-258 m deep; Indemares 4 exped.; MZB 2014-1471 • 1 colony; Menorca Channel, st. 90; same collection data as for preceding but 127-257 m deep; MZB 2014-5758. 


\section{Description}

Colony erect, irregularly branched in one plane, fan-shaped, vinculariform (not fenestrate), white, pink or orange-colored. Frontal faces bearing autozooids, abfrontal faces consisting of sheets of kenozooids.
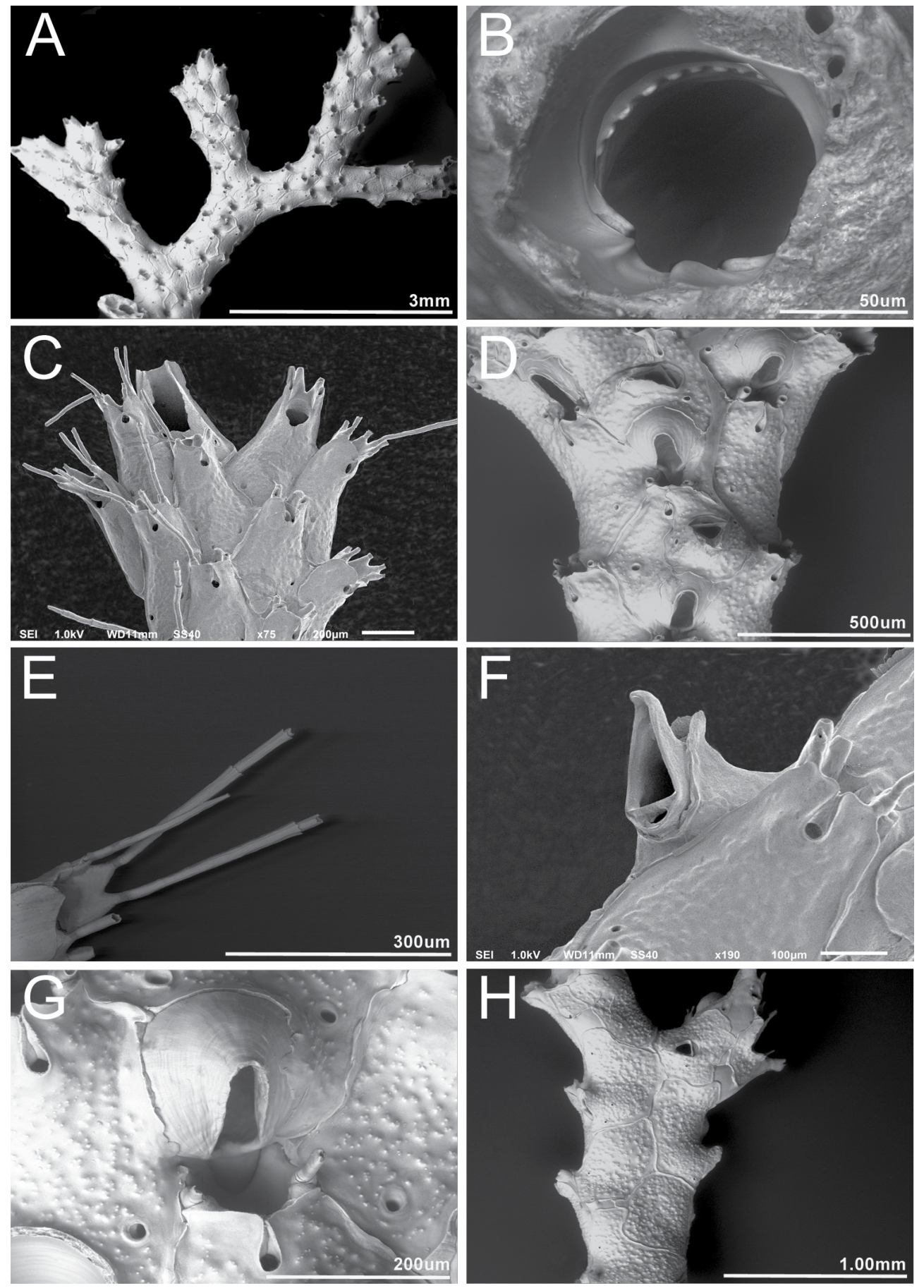

Fig. 5. Schizoretepora solanderia (Risso, 1826), Menorca Channel (A-B, D, G-H: MZB 2014-1471; C, E-F: MZB 2014-1486). A. Colony view. B. Detail of aperture. C. Growing margin with autozooids showing up to six spines. D. Older ovicellate autozooids with giant vicarious avicularia. E. Detail of articulated and carenated spines. F. Marginal avicularia showing nested piling of cystids. G. Details of ovicell. H. Abfrontal view with avicularia. 
Table 2. Measurements of Schizoretepora solanderia (Risso, 1826).

\begin{tabular}{cccccc}
\hline & N & MEAN & SD & MIN & MAX \\
\hline $\mathrm{TW}$ & 17 & 924 & 111 & 762 & 1164 \\
$\mathrm{Nz}$ & 17 & 3.2 & 0.4 & 3 & 4 \\
$\mathrm{AzL}$ & 44 & 473 & 43 & 355 & 565 \\
$\mathrm{AzW}$ & 39 & 279 & 30 & 222 & 337 \\
$\mathrm{ApL}$ & 12 & 102 & 20 & 79 & 145 \\
$\mathrm{ApW}$ & 19 & 108 & 10 & 91 & 130 \\
$\mathrm{OL}$ & 6 & 92 & 3 & 88 & 97 \\
$\mathrm{OW}$ & 6 & 89 & 7 & 79 & 97 \\
$\mathrm{VAL}$ & 25 & 205 & 41 & 144 & 321 \\
$\mathrm{VAW}$ & 24 & 102 & 11 & 80 & 118 \\
$\mathrm{AbAL}$ & 4 & 257 & 12 & 247 & 275 \\
$\mathrm{AbAW}$ & 3 & 108 & 14 & 99 & 124 \\
$\mathrm{OVL}$ & 18 & 204 & 19 & 162 & 229 \\
$\mathrm{OVW}$ & 17 & 191 & 15 & 161 & 214 \\
$\mathrm{Ns}$ & 50 & 3.6 & 1.4 & 2 & 6 \\
$\mathrm{~Np}$ & 28 & 2 & - & 2 & 2 \\
$\mathrm{~Np} \mathrm{Ab}$ & 11 & 3 & 0.8 & 3 & 4 \\
\hline
\end{tabular}

Branches thick, with on average four (2-5) rows of autozooids arranged quincuncially, with a serrate profile owing to the presence of giant vicarious avicularia (see below) (Fig. 5A).

Autozooids hexagonal, longer than wide, convex, separated by distinct sutures. Frontal slightly rugose, with two areolae, placed on the proximal part of the zooid (Fig. 5C).

Primary orifice always obscured by the peristome, longer than wide, distal rim with rounded denticles, proximal border with U-shaped sinus flanked by short, smooth and wide condyles (Fig. 5B). Peristome well-developed, forming tubular high collar; with drop-shaped long spiramen and upper slit cutting it in two plates (young zooids) (Fig. 5C), becoming shorter and smoother in older zooids (Fig. 5D).

More commonly four (5 to 6) long oral spines, articulated and carinated (Fig. 5E), with basal parts thickly fused in young zooids (Fig. 5C), only two and gradually disappearing in older zooids (Fig. 5D).

Two types of frontal triangular avicularia. Adventitious large avicularia on raised cystid, laterally directed, irregularly present, placed on the median line of frontal surface (Fig. 5D). Giant vicariant avicularia hooked, regularly present on lateral sides of branches, facing upwards and distolaterally directed, sometimes with up to three piling cystids (Fig. 5F). Both types with robust crossbar and lacking columella.

Ovicell typically globular, slightly longer than wide, hyperstomial in young zooids, immersed with secondary calcification, surface smooth, imperforate, with large central fissure, widening at base, noncleithral (Fig. 5G).

Abfrontal layer with two rows of large, rugose, polygonal kenozooids, with one to three pores and raised sutures. Abfrontal avicularia large, acute, triangular, sporadically present, more frequent near base of colony (Fig. 5H). 


\section{Remarks}

Until now, four oral spines have consistently been reported for S. solanderia (Calvet 1902; Gautier 1962). As shown in our specimens, however, the number of spines changes with ontogenetic development, with a higher number of spines on apical autozooids (up to six spines). Schizoretepora solanderia is easily distinguished from all other species of Schizoretepora by the well-developed peristome forming a high collar with a drop-like spiramen. Schizoretepora solanderia is rather common in the Mediterranean and north-eastern Atlantic on coralligenous and detritic bottoms from 30 to $300 \mathrm{~m}$ deep.

Schizoretepora dentata (Calvet, 1931)

Fig. 6

Schizellozoon dentatum Calvet, 1931: 107, pl. II, fig. 16.

\section{Material examined}

\section{Holotype}

AÇORES • 1 fragment; $38^{\circ} 27^{\prime} \mathrm{N}, 28^{\circ} 03^{\prime} 25^{\prime \prime} \mathrm{W}$; $523 \mathrm{~m}$ deep; on rock; scientific survey from 1895 by Prince Albert I from Monaco exped., st. 597, 23 Jul. 1895; MOM INV-22494-42 0559.

\section{Remarks}

This species has never been found again after its description. Calvet (1931) remarked the similarities of $S$. dentata with $S$. solanderia, pointing to the distinctive backed zooids and the presence of two avicularia on each autozooid (Fig. 6A). We examined the type specimen housed at the MOM that, unfortunately, is badly damaged and does not allow a detailed description or measurements (Fig. 6B). There is no further available material for this species. The lack of some features in the described type specimen, which are diagnostic of the genus (i.e., complete ovicell) makes the ascription of this species to Schizoretepora uncertain.
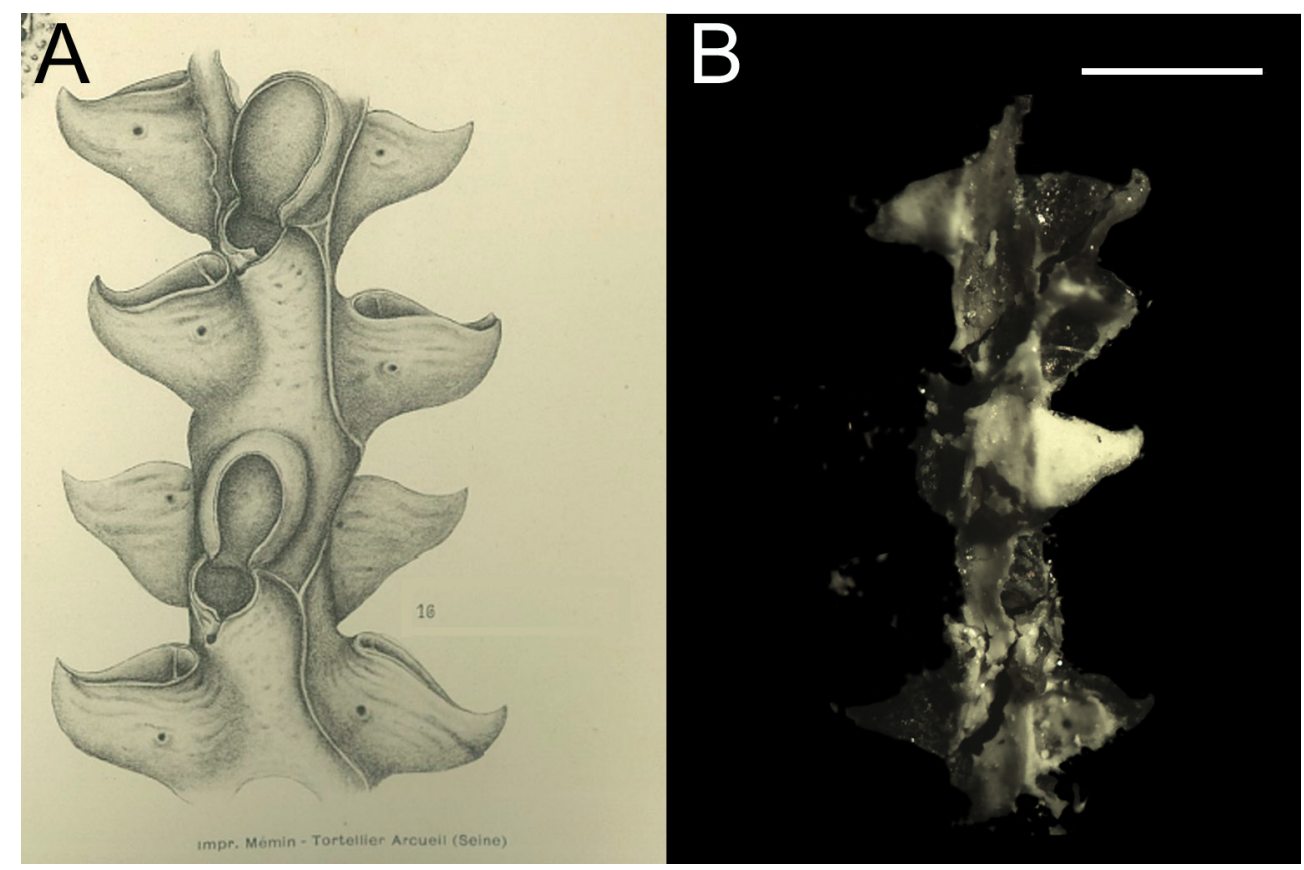

Fig. 6. Available characteristics of Schizoretepora dentata (Calvet, 1931). A. Original drawing from Calvet (1931). B. Actual condition of the type housed at MOM. Scale bar: $1 \mathrm{~mm}$. 
Schizoretepora aviculifera (Canu \& Bassler, 1930)

Fig. 7, Table 3

Schizellozoon aviculiferum Canu \& Bassler, 1930: 60-62, pl. VIII, figs 1-13.

Schizellozoon granulosum Canu \& Bassler, 1930: 62-63, pl. VII, figs 6-8.

\section{Material examined}

Holotype (by original designation)

TUNISIA • 3 fragments; Kerkennah Is.; Canu coll.; labelled Schizellozoon aviculiferum (specimen figured in original publication); MNHN-IB-2014-24.

\section{Other material}

TUNISIA 3 fragments; Sfax; Canu coll.; labelled Schizellozoon granulosum (syntype specimen figured in original publication); MNHN-IB-2014-21 1 colony; Golfe de Gabés, st. 17; Nov. 1953; Y.V Gautier and J. Picard leg.; labelled Schizellozoon aviculiferum; MNHN-IB-2008-11126 - 2 colonies; same collection data as for preceding; Gautier leg.; labelled Schizellozoon longisetae; MNHN-IB-2008-11127.

\section{Description}

Colony erect, regularly fenestrate (reteporiform) (Fig. 7A); frontal faces bearing autozooids, abfrontal faces consisting of sheets of kenozooids. Color not noted in live material. Old colonies strongly calcified, branches thick, trabeculae with 3-6 longitudinal rows of autozooids arranged quincuncially (Fig. 7D, F). Fenestrae oval, small, often equal or smaller in width than trabeculae (Fig. 7A, D).

Autozooids longer than wide, convex, separated by distinct raised sutures. Frontal shield notably nodular, with 6-8 conspicuous areolae (Fig. 7E).

Primary orifice semi-elliptical, as long as wide, distal rim with 16-18 blunt denticles, proximal border with U-shaped sinus (wider than long), framed by two acute denticles that form a gutter on the proximal peristomial rim, and flanked by smooth condyles, sloping towards the edges of the sinus (Fig. 7B).

Peristome relatively low, variably developed following ontogeny, with proximal lateral flanges distinctly rounded (when compared with $S$. longisetae and S. imperati) on younger zooids (Fig. 7C), smothered in older zooids (Fig. 7F).

Two to six long oral spines, commonly 4-5 in young zooids, articulated (i.e., telescopic) and carinated (Fig. 7C), with basal parts thickly fused in distal zooids, one of them particularly large and thick, clublike (Fig. 7E). Spines fragile and easily broken off, only two bases remaining in older zooids (Fig. 7B).

Two types of frontal avicularia. Adventitious avicularia almond-like, with triangular hooked tip, typically proximo-lateral to orifice and directed disto-laterally (Fig. 7E), with slender crossbar and without columella. Giant avicularia on raised cystid (with 2-5 pores) (Fig. 7F); orientated perpendicular to frontal plane and directed proximo-laterally; similar in shape to almond-like adventitious avicularia, triangular but with straight borders and a strongly hooked tip; crossbar robust, without columella. Giant and almond-like adventitious avicularia rarely occur in same zooid, the former being more abundant on the central part of branches.

Ovicell typically globular, non-cleithral (Fig. 7F), slightly wider than long, hyperstomial in young zooids, subimmersed with secondary calcification; surface rugose imperforate, with large central fissure, widening at the base. 

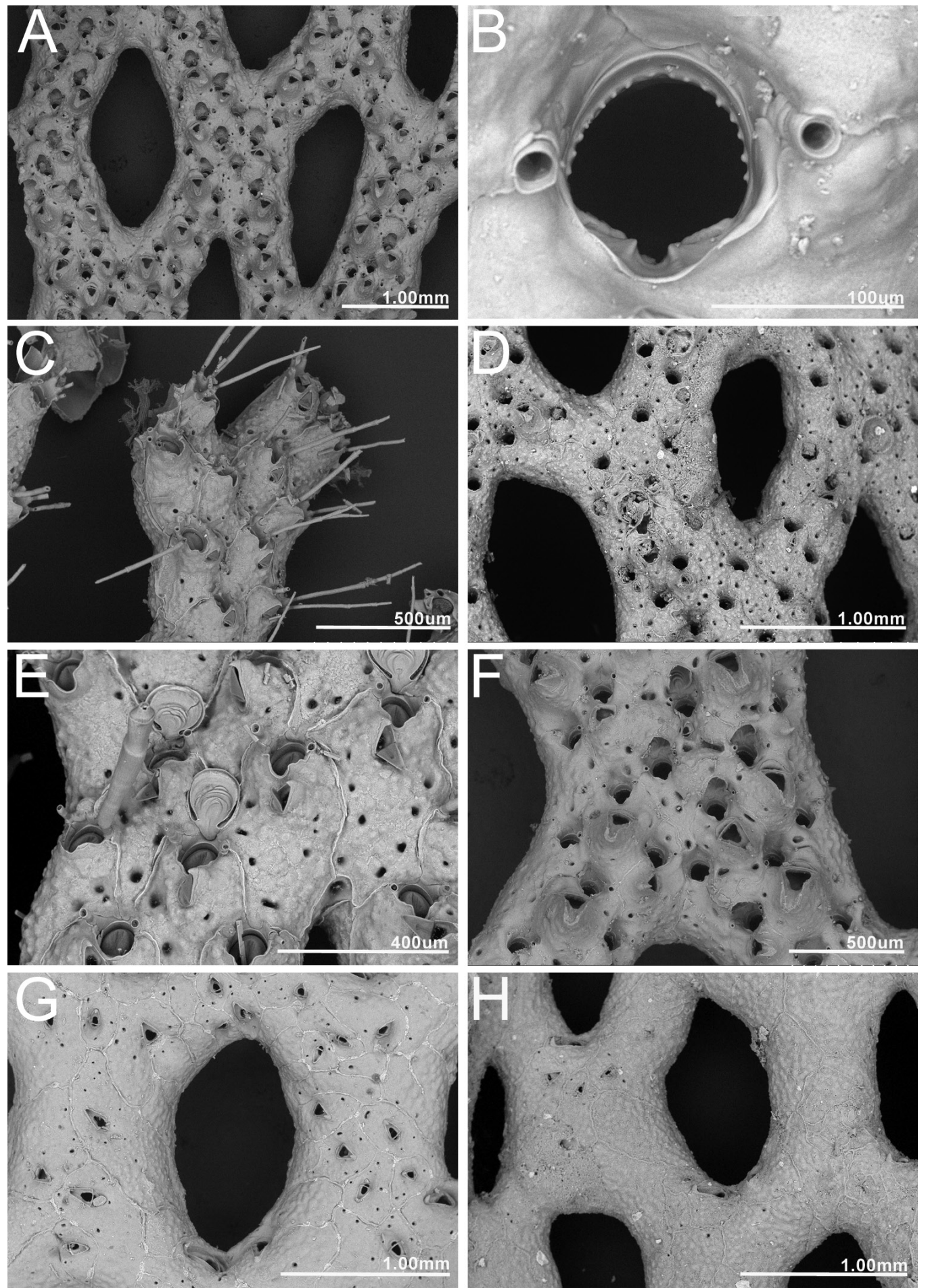

Fig. 7. Schizoretepora aviculifera (Canu \& Bassler, 1930). A-B, F-G from Schizellozoon aviculiferum, holotype, coll. Canu (MNHN-IB-2014-24); C from specimen labelled as Schizellozoon longisetae (MNHN-IB-2008-11127); D, H from Schizellozoon granulosum, syntype, coll. Canu (MNHNIB-2014-21); E from Schizellozoon aviculiferum (MNHN-IB-2008-11126). A. Frontal colony view. B. Primary orifice detail. C. Apical view of colony (note the articulated and carenated spines). D. Old ovicellate colony. E. Detail of young autozooids showing ovicells in formation and adventitiuos avicularia (note the giant club-like spine). F. Ovicellate zooids. G. Abfrontal view with avicularia. H. Abfrontal view showing triangular avicularia. 
Table 3. Measurements of Schizoretepora aviculifera (Canu \& Bassler, 1930).

\begin{tabular}{cccccc}
\hline & N & MEAN & SD & MIN & MAX \\
\hline FL & 55 & 1320 & 207 & 746 & 1774 \\
$\mathrm{FW}$ & 55 & 679 & 160 & 393 & 1056 \\
$\mathrm{TW}$ & 100 & 744 & 251 & 385 & 1632 \\
$\mathrm{Nz}$ & 93 & 4 & 1 & 2 & 6 \\
$\mathrm{AzL}$ & 142 & 411 & 51 & 278 & 542 \\
$\mathrm{AzW}$ & 143 & 261 & 35 & 167 & 386 \\
$\mathrm{OL}$ & 71 & 80 & 8 & 66 & 97 \\
$\mathrm{OW}$ & 71 & 80 & 8 & 60 & 97 \\
$\mathrm{ApL}$ & 48 & 109 & 10 & 89 & 130 \\
$\mathrm{ApW}$ & 48 & 109 & 9 & 94 & 129 \\
$\mathrm{AAL}$ & 80 & 88 & 15 & 46 & 127 \\
$\mathrm{AAW}$ & 80 & 45 & 9 & 29 & 73 \\
$\mathrm{VAL}$ & 71 & 174 & 48 & 106 & 296 \\
$\mathrm{VAW}$ & 71 & 90 & 25 & 51 & 159 \\
$\mathrm{OVL}$ & 40 & 200 & 29 & 132 & 252 \\
$\mathrm{OVW}$ & 40 & 230 & 22 & 189 & 279 \\
$\mathrm{AbAL}$ & 71 & 149 & 53 & 73 & 327 \\
$\mathrm{AbAW}$ & 71 & 74 & 25 & 35 & 140 \\
$\mathrm{AbVL}$ & 3 & 195 & 51 & 139 & 237 \\
$\mathrm{AbVW}$ & 3 & 75 & 6 & 68 & 79 \\
$\mathrm{Ns}$ & 92 & 3 & 1 & 2 & 6 \\
$\mathrm{~Np}$ & 141 & 4 & 1 & 1 & 7 \\
$\mathrm{~Np} \_\mathrm{Ab}$ & 51 & 3 & 1 & 1 & 6 \\
\hline & & & & &
\end{tabular}

Abfrontal convex and notably nodular (Fig. 7H), with large polygonal kenozooids separated by raised sutures, and numerous pores ( 2 to 8 ). Abfrontal avicularia always triangular, with straight margins, hooked, variable in number but occasionally very numerous (Fig. 7G), of two different sizes, larger on the basis of the fenestrae; with slender crossbar, wide triangular lacuna and without columella. Base of the colonies with numerous kenozooids bearing small oval avicularia.

\section{Remarks}

The descriptions by Canu \& Bassler of $S$. aviculiferum and S. granulosum are unfortunate, because they are based on very old material, abraded and fragmented. In particular, they failed to observe the total number of spines and other details of young zooids. The specimens of $S$. aviculiferum collected by Gautier (MNHN-IB-2008-11126) are the best-preserved and show all the characters well. Gautier mistakenly ascribed the specimen MNHN-IB-2008-11127 to S. longisetae (see Fig. 7C).

To date, $S$. aviculiferum has been considered a synonym of the former $S$. imperati (now S. pungens), as suggested by Barrosso (1935), Zabala (1986), d'Hondt \& Ben Ismail (2008) and Rosso \& Di Martino (2016). Barroso (1935) noted that the differences between S. imperati and S. aviculiferum (and also S. pungens) are limited and of "secondary order", suggesting that they were probably the same species. 
Schizoretepora granulosa was never reported again after its description and it was recently considered an equivocal report by Rosso \& Di Martino (2016). Canu \& Bassler (1930) in their description of $S$. granulosum pointed out that this species is very similar to $S$. pungens, the only differences being the grainy frontal and the absence of abfrontal avicularia. Despite most fragments being very calcified, thus the abfrontal avicularia are probably embedded by secondary calcification, an accurate revision of Canu \& Bassler's material (Fig. 7H) reveals the presence of the characteristic triangular avicularia.

Overall, the descriptions of $S$. aviculiferum and S. granulosum were thus based on different parts of the colony and different growth stages that rendered equivocal characters to identify the species. The detailed examination of museum specimens together with the morphometric analysis presented here indicate that both species are the same, characterized by having only one type of frontal adventitious avicularia (triangular) and numerous abfrontal triangular avicularia.

Schizoretepora hassi (Harmelin, Bitar \& Zibrowius, 2007) shows great similarities with S. aviculifera, particularly with the presence of frequent abfrontal avicularia (more abundant at the base of the colony in $S$. hassi), the adventitious avicularia typically located proximo-laterally to the orifice and the nodular aspect of the frontal. Differences between $S$. hassi and S. aviculifera are mainly based on the morphology of the colony and also on measurements, generally larger in $S$. hassi.

Schizoretepora aviculifera is very similar to $S$. pungens and differences between both species are very subtle. These differences are explained below (see remarks for S. longisetae).

Schizoretepora hassi Harmelin, Bitar \& Zibrowius, 2007

Schizoretepora hassi Harmelin et al., 2007: 181, figs 1-2, 3a.

Schizoretepora hassi-Sokolover et al. 2016: 443.

\section{Remarks}

Schizoretepora hassi occurs in the eastern Mediterranean (Lebanon coast) only and is found in shaded rocky habitats between 3 and $36 \mathrm{~m}$ deep. Its origin is unresolved, being either a steno-endemic in the Levantine Basin or an Erythraean immigrant (Harmelin et al. 2007). This species shows a great variability in colony shape, from fenestrate to ramose and bilaminated as well as a large variability in the zooidal characters, frontal shield and number of avicularia depending on their position, age and locality (Harmelin et al. 2007). Schizoretepora hassi is very similar to $S$. aviculifera (see remarks above).

Schizoretepora imperati (Busk, 1884)

Fig. 8, Table 4

Retepora imperati Busk, 1884: 110, pl. XXVI, fig 9.

Non Retepora imperati-Waters 1894: 262; 1925: 659.

Non Schizellozoon imperati - Canu \& Bassler 1928: 49-50, pl. IV, fig. 10. — Barroso 1935: 378, fig. 6a-d.

Non Schizoretepora imperati - Gautier 1962: 235-236.

\section{Material examined}

\section{Syntypes}

CAPE VERDE ISLANDS • 1 colony; Porto Praya; 100-120 fathoms deep; Challenger exped. [ex Dundee museum collection]; labelled Retepora imperati; NHMUK 1963.2.12.202 • 1 colony; same collection data as for preceding; NHMUK 1934.2.16.23. 
Table 4. Measurements of Schizoretepora imperati (Busk, 1884).

\begin{tabular}{cccccc}
\hline & N & MEAN & SD & MIN & MAX \\
\hline FL & 16 & 1508 & 299 & 1082 & 1949 \\
$\mathrm{FW}$ & 25 & 703 & 167 & 350 & 1064 \\
$\mathrm{TW}$ & 44 & 627 & 131 & 389 & 907 \\
$\mathrm{Nz}$ & 19 & 3 & 1 & 2 & 5 \\
$\mathrm{AzL}$ & 30 & 471 & 53 & 326 & 594 \\
$\mathrm{AzW}$ & 25 & 323 & 36 & 271 & 408 \\
$\mathrm{OL}$ & 15 & 108 & 8 & 96 & 124 \\
$\mathrm{OW}$ & 14 & 86 & 5 & 78 & 98 \\
$\mathrm{ApL}$ & 23 & 135 & 13 & 111 & 162 \\
$\mathrm{ApW}$ & 28 & 104 & 9 & 87 & 126 \\
$\mathrm{VAL}$ & 12 & 183 & 22 & 160 & 232 \\
$\mathrm{VAW}$ & 20 & 109 & 17 & 71 & 136 \\
$\mathrm{OVL}$ & 20 & 200 & 55 & 140 & 321 \\
$\mathrm{OVW}$ & 13 & 168 & 35 & 130 & 261 \\
$\mathrm{AbAL}$ & 40 & 146 & 18 & 100 & 180 \\
$\mathrm{AbAW}$ & 41 & 67 & 10 & 45 & 90 \\
$\mathrm{Ns}$ & 28 & 2 & 0 & 2 & 2 \\
$\mathrm{~Np}$ & 58 & 3 & 1 & 2 & 5 \\
$\mathrm{~Np}$ Ab & 36 & 5 & 3 & 1 & 12 \\
\hline
\end{tabular}

ALGERIA - 1 colony; Oran; [sent to A.M. Norman by A.W. Waters] labelled Retepora imperati; NHMUK 1911.10.1.813 1 colony; same collection data as for preceeding but coll. Mr Alder; A.M. Norman leg.; labelled Retepora imperati; NHMUK 1911.10.1.814 2 colonies, several fragments; same collection data as for preceding; coll. Canu; labelled Retepora imperati; MNHN-IB-2014-29 • 1 colony; same collection data as for preceding; coll. Calvet; labelled Retepora imperati; MNHN-IB-2008-6052 • 1 colony; same collection data as for preceding; MNHN-IB-2008-982 1 colony; same collection data as for preceding; MNHN-IB-2008-983.

ITALY 1 colony; Sicily, Palermo; Marquis di Monterosto leg., coll. A.M. Norman; labelled Retepora imperati; NHMUK 1911.10.1.1374.

MOROCCO - 2 colonies; st CX, 1926, R/V Vanneau exped.; coll. Canu; labelled Retepora imperati; MNHN-IB-2008-9955 • 1 colony; SW Alboran Sea, st. 1294; 3 Sep. 1958; R/V Calypso; coll. Gautier; labelled Retepora imperati; MNHN-IB-2008-11299.

\section{Description}

Colony erect, regularly fenestrate (reteporiform); frontal surfaces bearing autozooids, abfrontal faces consisting of sheets of kenozooids. Trabeculae with 2-4 longitudinal rows of autozooids arranged quincuncially. Fenestrae oval, longer than wide (Fig. 8A).

Autozooids ovoid, longer than wide, convex, separated by distinct raised sutures. Frontal shield smooth or finely rugose, with $2-4$ areolae (Fig. 8C-D).

Primary orifice semi-elliptical, longer than wide, distal rim with 16-18 blunt, triangular denticles, proximal border with U-shaped sinus (wider than long) and flanked by smooth condyles, sloping towards the edges of the sinus (Fig. 8B). 
Peristome thin, slightly raised on both sides of orifice (Fig. 8C). Autozooids with two oral spines (only the bases observed), one with thicker diameter (Fig. 8B). Giant avicularia on a large cystid (with 2 pores), in the middle of frontal plane, rostrum triangular with slightly concave margins and hooked tip, laterally directed, crossbar robust and without columella (Fig. 8C).

Ovicell typically globular, longer than wide, immersed with secondary calcification, surface smooth, imperforate, with large central fissure, widening at base, non-cleithral (Fig. 8E).
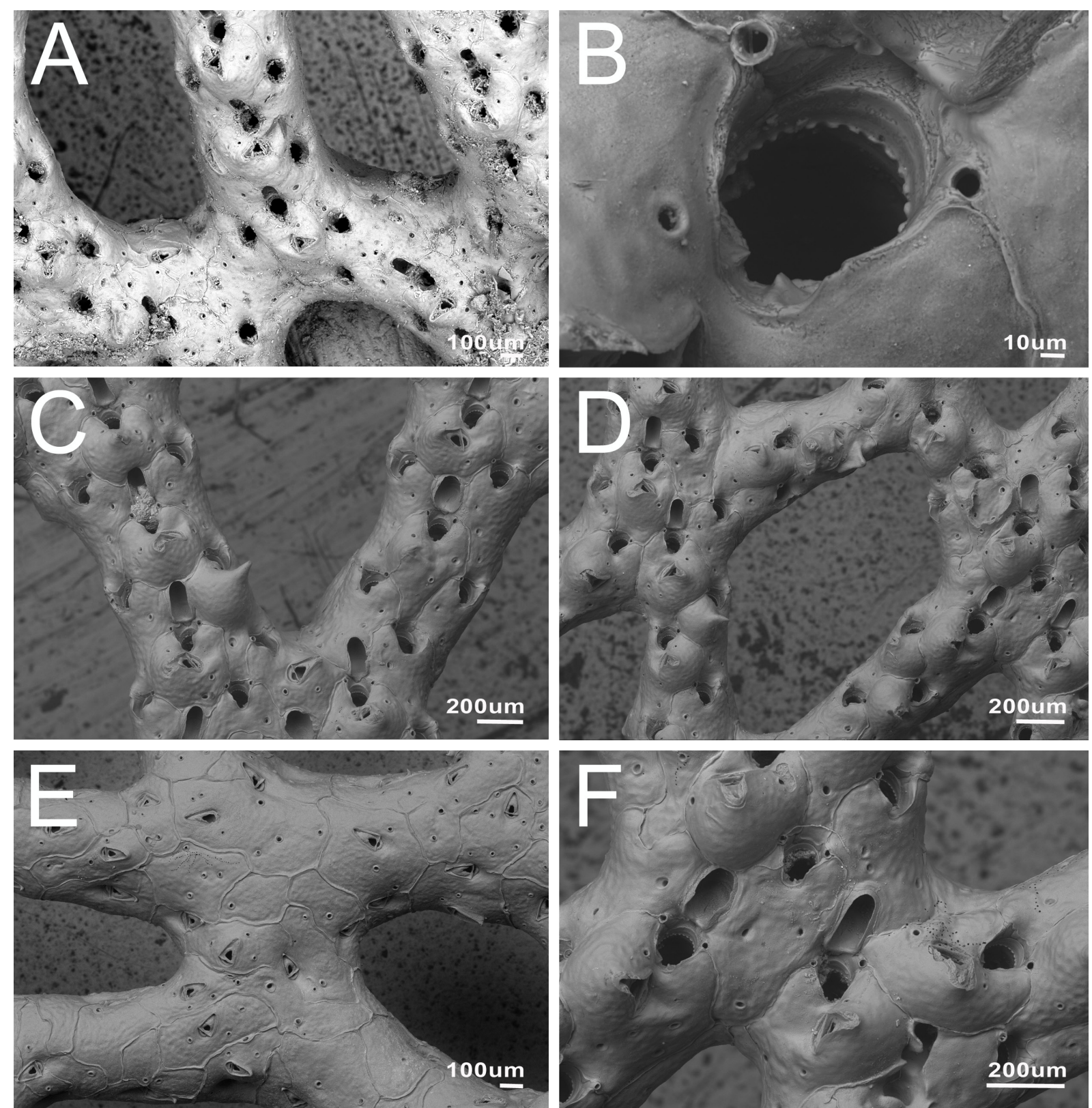

Fig. 8. Schizoretepora imperati (Busk, 1884). A from Retepora imperati, syntype (NHMUK 1963.2.12.202); B-F from Retepora imperati, syntype (NHMUK 1934.2.16.23). A. Colony, frontal view. B. Primary orifice, detail. C-D. Ovicellated autozooids with giant avicularia. E. Detail of ovicellated autozooid with giant avicularia. F. Abfrontal view with triangular avicularians. 
Abfrontal slightly granular, with large polygonal kenozooids separated by raised sutures. Two types of abfrontal avicularia, adventitious triangular, scattered around kenozooids, and giant avicularia typically located at base of fenestrae, triangular (Fig. 8F).

\section{Remarks}

Spines were not reported by Busk (1884) in the original description, but the study of his own material reveals the presence of the remaining holes. The giant abfrontal avicularium is rare in the material provided (syntypes); however, Busk (1884) already reported their presence, as did Waters (1895). Since no young or apical parts remain in the type material, it cannot be ascertained whether young zooids present the two triangular flaps characteristic of other nearer species (i.e., S. pungens, see Figs 9E, 10C); thus, this difference could also be due to ontogenetic changes.

S. imperati (Busk) differs from S. pungens in:

- lacking oval adventitious avicularia both frontal and abfrontal

- the shape of abfrontal adventitious avicularia, triangular in S. imperati (Busk) (Fig. 8F) but oval or almond-shaped in S. pungens (Fig. 10E-F)

- in the shape of the peristome, thinner in S. imperati. Indeed, in the type material we did not observe the distinctively pointed lateral flaps characteristic of S. pungens (Figs 9C-D; 10C), though these were included in the original description (Busk 1884), and it could be a character associated with young zooids

The abfrontal of $S$. imperati (Busk) is closer to that of $S$. aviculifera (as described here) as both have numerous triangular avicularia, but they differ on the rugosity of the surface (Figs $7 \mathrm{H}, 8 \mathrm{~F}$ ), being smoother in S. imperati (Busk). They differ on the frontal face because of the presence of almond-like avicularia in $S$. aviculifera (Fig. 7E), always missing in $S$. imperati (Busk) (Fig. 8C-D).

Schizoretepora pungens (Canu \& Bassler, 1925)

Figs 9-10, Table 5

Schizellozoon pungens Canu \& Bassler, 1925: 45-46, pl. IV, figs 1-3.

Schizoretepora longisetae Canu \& Bassler, 1928: 51, pl. VI, figs 7-10.

Retepora imperati - Waters 1894: 262; 1925: 659.

Schizellozoon imperati - Canu \& Bassler 1928: 49-50, pl. IV, fig. 10. - Barroso 1935: 378, fig. 6a-d.

Schizellozoon pungens - Canu \& Bassler 1928: 50, pl. IV, fig. 9.

Schizoretepora imperati - Gautier 1962: 235-236.

Non Schizoretepora longisetae - Gautier 1962: 236-237.

\section{Type material}

Holotype

MOROCCO - 3 fragments; Moroccan coast; coll. Canu; labelled Schizellozoon pungens [specimen figured in original publication]; MNHN-IB-2014-19.

\section{Syntype}

MOROCCO $• 3$ fragments; same collection data as for preceding; MNHN-IB-2014-20.

\section{Other material examined}

ALGERIA • 1 colony; Oran; sent to A.M. Norman by A.W. Waters; labelled Retepora imperati; NHMUK 1911.10.1.813 - 1 colony; same collection data as for preceding; coll. Mr Alder; A.M. Norman leg.; labelled Retepora imperati; NHMUK 1911.10.1.814 • 3 fragments; same collection data as for preceding; 

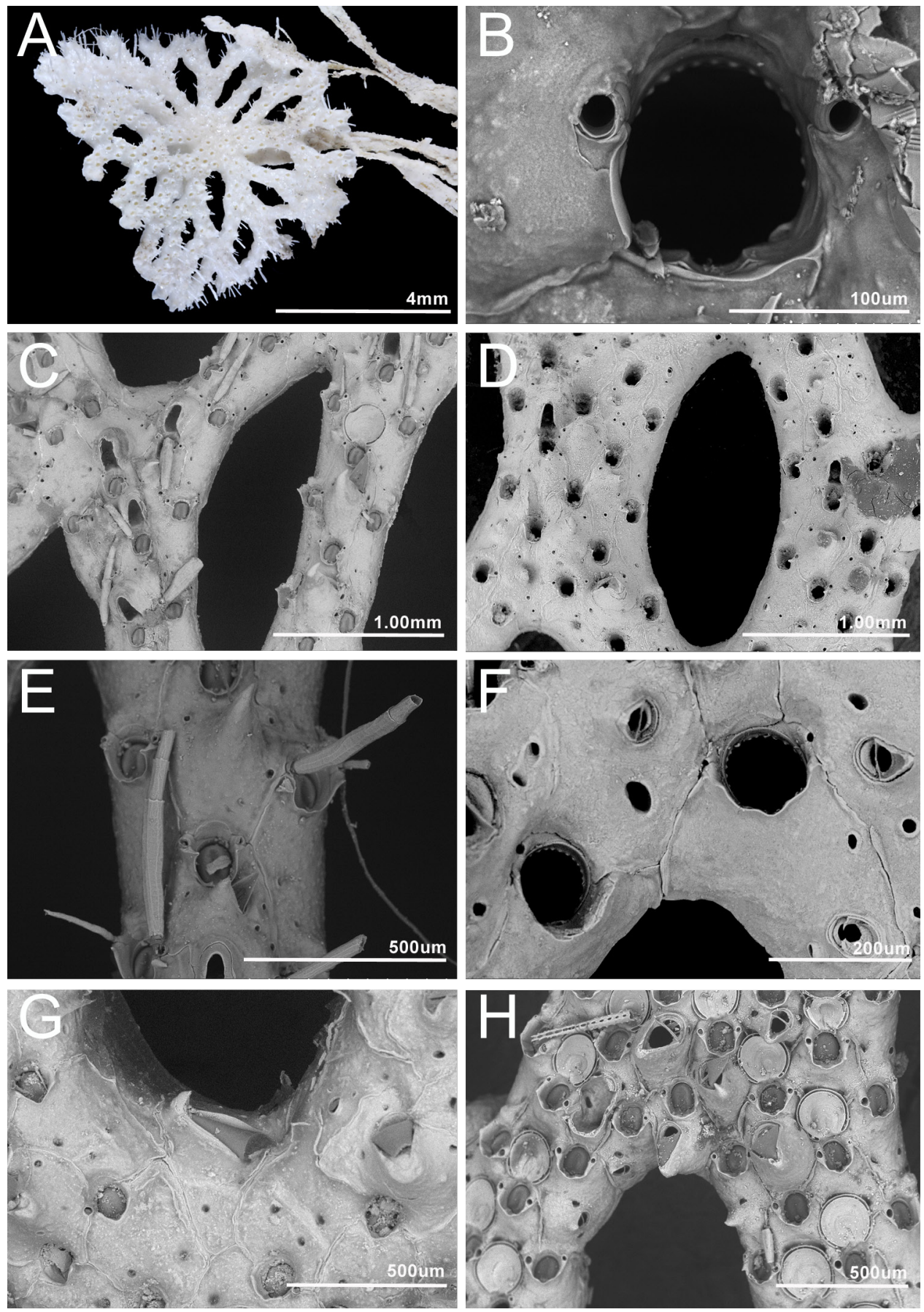

Fig. 9. Schizoretepora pungens (Canu \& Bassler, 1925). A from specimen labelled as Schizellozoon longisetae, Gautier leg. (MNHN-IB-2008-11127); B, H from specimen labelled as Retepora imperati, coll. Canu (MNHN-IB-2014-29); C from specimen labelled as Schizellozoon longisetae (MNHNIB-2008-14462); D from Schizoretepora pungens, holotype, coll. Canu (MNHN-IB-2014-20); E from Schizoretepora pungens (MNHN-IB-2008-14434); F from specimen labelled as Retepora imperati (MNHN-IB-2008-982); G from specimen labelled as Retepora imperati, coll Calvet (MNHNIB-2008-6052). A. Young colony with spines. B. Primary orifice showing distal denticles, proximal condyles, sinus and smothered peristome. C. Young autozooids showing spines and acute peristomes. D. Old autozooids lacking spines and with smothered peristomes. E. Detailed view of articulated and carenated club-like spines. F. Adventitious triangular (upper side) and oval (bottom right) avicularians. G. Giant avicularium at basis of fenestra. H. Giant avicularia on large cystids showing crossbar without columella. 

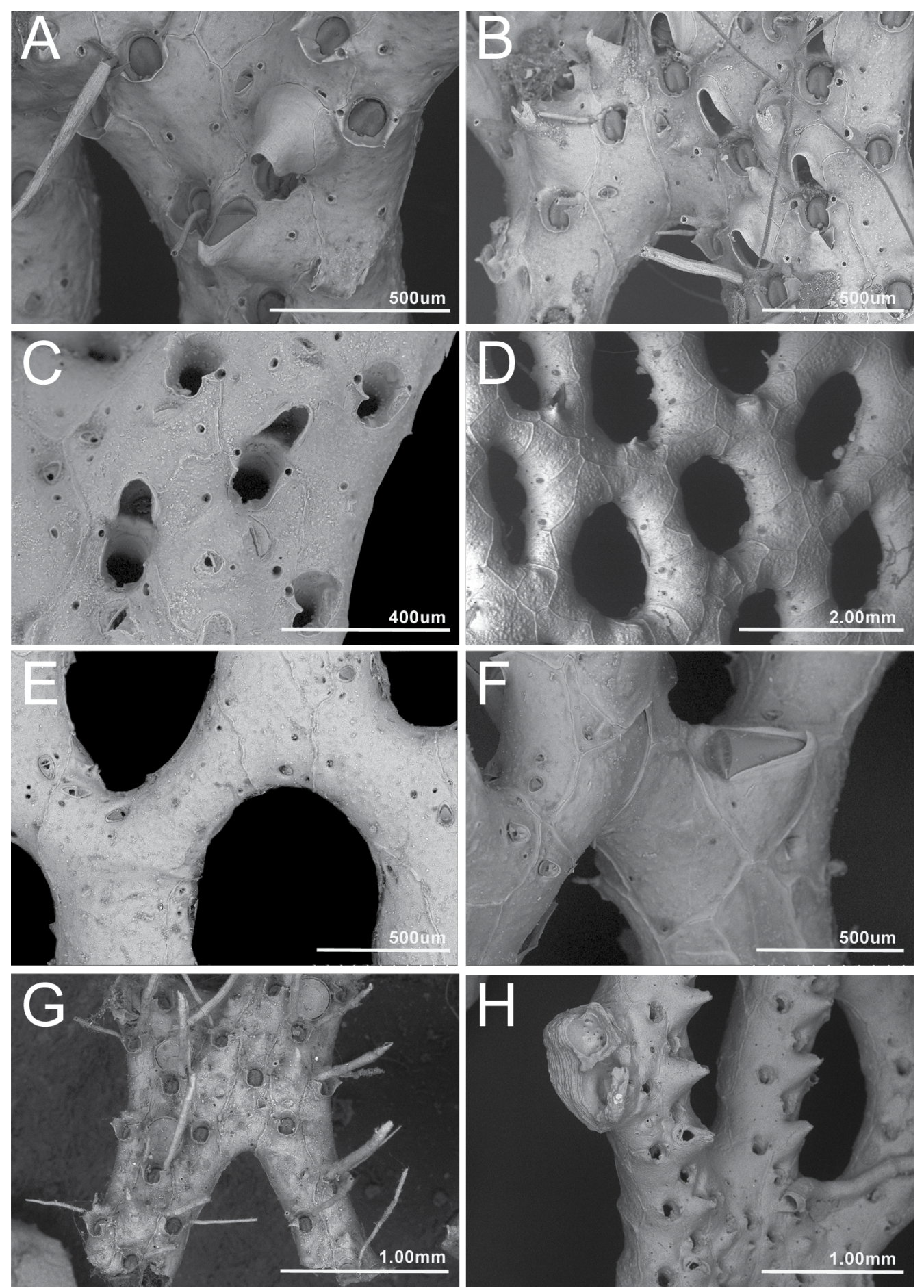

Fig. 10. Schizoretepora pungens (Canu \& Bassler, 1925). A from Schizoretepora imperati, coll. Gautier (MNHN-IB-2008-11299); B, F from Schizoretepora pungens (MNHN-IB-2008-14434); C from Schizoretepora pungens, holotype, coll. Canu (MNHN-IB-2014-20); D from specimen labelled as Schizoretepora imperati (MNHN-IB-2008-9955); E, G from specimen labelled as Schizoretepora longisetae, coll. Canu (MNHN-IB-2014-19); H from Schizoretepora pungens (MNHN-IB-2008-14045). A-B. Two ovicell aspects in young colonies. C. Deeply immersed ovicells in older colonies. D. Abfrontal face showing rugose kenozooids separated by raised sutures. E. Abfrontal face showing two types of adventitious avicularia, both oval and almond-shaped. F. Abfrontal detail of giant avicularium at the basis of a fenestra and small oval avicularia. G. Aspect of spinose colony. H. Aspect of serrated colony. 
st 54bv; coll. Canu; labelled Retepora imperati; MNHN-IB-2014-29 • 1 colony; same collection data as for preceding; coll. Calvet; labelled Retepora imperati; MNHN-IB-2008-6052 - 1 colony; same collection data as for preceding; MNHN-IB-2008-982 • 1 colony; same collection data as for preceding; MNHN-IB-2008-983.

ITALY • 1 colony; Sicily, Palermo; Marquis di Monterosto leg.; coll. A.M. Norman; labelled Retepora imperati; NHMUK 1911.10.1.1374.

MOROCCO - 1 colony; st CX, 1926, R/V Vanneau exped.; coll Canu; labelled Retepora imperati; MNHN-IB-2008-9955 • 1 colony; SW Alboran Sea; St. 1294; 3 Sep. 1958; R/V Calypso exped.; coll Gautier; labelled Retepora imperati; MNHN-IB-2008-11299 • 1 colony; Catiglione 53, st. E; coll. Gautier; labelled Retepora imperati; NHMUK 1965.9.2.30 • 1 colony; Moroccan coast; St. XXXVII; R/V Vanneau exped.; 7 Jun. 1924; Canu and Bassler leg., coll. Canu; labelled Schizellozoon longisetae; MNHN-IB-2008-14462 1 colony; same collection data as for preceding; St. XLIII; 19 Jun. 1924; labelled Schizellozoon longisetae; MNHN-IB-2008-14327 • 1 colony; same collection data as for preceding; St. CXXVIII; 28 Aug. 1926; labelled Schizellozoon longisetae; MNHN-IB-2008-14081 • 1 colony; same collection data as for preceding; 9 Oct. 1925; labelled Schizoretepora pungens; MNHN-IB-2008-14434 - 2 fragments; same collection data as for preceding; St, LXII; $110 \mathrm{~m}$ deep; 15 Aug. 1925; labelled Schizoretepora pungens; MNHN-IB-2008-14680 - 1 colony; same collection data as for preceding; St. CXXVI; 27 Aug. 1926; labelled Schizoretepora pungens; MNHN-IB-2008-14045 • 3 fragments; same collection data as for preceding; St. XXXI; labelled Schizoretepora pungens; MNHN-IB-2014-31.

\section{Description}

Colony erect, regularly fenestrate (reteporiform); frontal faces bearing autozooids, abfrontal faces consisting of sheets of kenozooids. Branches thick, trabeculae with 3-6 longitudinal rows of autozooids arranged quincuncially. Fenestrae oval, 1-2 times as wide as trabeculae (Fig. 9A). Frontal aspect of colony very variable, from spinose (longisetae type) to serrated (pungens type) (see differences between Fig. $10 \mathrm{G}$ and $\mathrm{H})$.

Autozooids longer than wide, convex, separated by distinct raised sutures. Frontal shield smooth (longisetae type) (Fig. 9C) or finely rugose (pungens type) (Figs 9D, 10B), with 2-5 areolae, more abundant in young zooids (longisetae type).

Primary orifice semi-elliptical, longer than wide, distal rim with 16-18 (18-24 in pungens type) blunt, triangular denticles, proximal border with $U$-shaped sinus (wider than long) framed by two acute denticles that form a gutter on proximal peristomial rim, and flanked by smooth condyles, sloping towards edges of sinus (Fig. 9B).

Peristome variably developed following ontogenetic development. It expands proximally and laterally, but not distally (between spines), as two triangular lateral flaps, distinctly pointed (young zooids) (Fig. 9C, E), that become smoother with ontogeny (Fig. 9B, D, F).

Two to four long oral spines, articulated and carinate, with basal parts thickly fused in distal young zooids, one of them particularly large and thick, club-like (Fig. 9C, E). Spines fragile and easily broken, only two of their bases remaining in older zooids (Fig. 9B, D).

Three types of frontal avicularia. Adventitious avicularia with two shapes, oval (round distal mandible) and almond-like (triangular distal mandible), both irregularly present, scattered proximally to the orifice and variably directed, with slender crossbar and without columella (Figs 9F, 10B-C). Giant vicarious avicularia on a large cystid (with 2-5 pores), in the middle of the frontal plane and at the basis of the fenestrae (Fig. 9G); rostrum triangular with hooked tip (Fig. 10A), variably (but never distally) directed, crossbar robust, without a columella (Fig. 9H). 
Table 5. Measurements of Schizoretepora pungens (Canu \& Bassler, 1925).

\begin{tabular}{cccccc}
\hline & N & MEAN & SD & MIN & MAX \\
\hline FL & 129 & 1589 & 343 & 961 & 2607 \\
FW & 190 & 681 & 162 & 374 & 1184 \\
TW & 341 & 702 & 236 & 325 & 2013 \\
$\mathrm{Nz}$ & 156 & 4 & 1 & 2 & 6 \\
$\mathrm{AzL}$ & 336 & 475 & 65 & 322 & 663 \\
$\mathrm{AzW}$ & 384 & 275 & 54 & 147 & 449 \\
OL & 268 & 106 & 9 & 84 & 129 \\
OW & 224 & 85 & 13 & 31 & 108 \\
$\mathrm{ApL}$ & 177 & 142 & 19 & 101 & 188 \\
$\mathrm{ApW}$ & 255 & 113 & 15 & 75 & 150 \\
$\mathrm{AAL}$ & 183 & 67 & 14 & 35 & 119 \\
$\mathrm{AAW}$ & 192 & 44 & 9 & 21 & 76 \\
$\mathrm{VAL}$ & 182 & 161 & 40 & 80 & 295 \\
$\mathrm{VAW}$ & 211 & 103 & 27 & 50 & 181 \\
$\mathrm{OVL}$ & 332 & 225 & 35 & 120 & 333 \\
$\mathrm{OVW}$ & 336 & 195 & 28 & 102 & 278 \\
$\mathrm{AbAL}$ & 107 & 71 & 16 & 31 & 126 \\
$\mathrm{AbAW}$ & 95 & 45 & 11 & 21 & 72 \\
$\mathrm{AbVL}$ & 55 & 257 & 58 & 110 & 363 \\
$\mathrm{AbVW}$ & 29 & 129 & 44 & 45 & 198 \\
$\mathrm{Ns}$ & 282 & 2 & 1 & 1 & 5 \\
$\mathrm{~Np}$ & 240 & 3 & 1 & 1 & 5 \\
$\mathrm{~Np}$ Ab & 81 & 3 & 1 & 1 & 5 \\
\hline
\end{tabular}

Ovicell typically globular, longer than wide, hyperstomial in young zooids (Fig. 10A-B), immersed with secondary calcification (Fig. 10C), surface smooth, imperforate, with large central fissure, widening at the base, non-cleithral.

Abfrontal layer slightly rugose, with large polygonal kenozooids separated by raised sutures and pores (Fig. 10D). Three types of abfrontal avicularia. Adventitious both oval and almond-like small avicularia (similar to those on the frontal), scattered around the kenozooids, variable in number (often more than 3 ) and orientation (Fig. 10E-F). Giant vicarious avicularia typically located close to fenestrae, triangular, with thin and large mandibles, and often distally hooked (Fig. 10F). Base of colonies with numerous kenozooids bearing small oval avicularia.

\section{Remarks}

All material coming from the Mediterranean Sea previously identified as $S$. imperati (Busk) (except $S$. “imperati" sensu O'Donoghue \& de Watteville 1939, see description below) as well as all material from the eastern Atlantic examined for $S$. longisetae belongs to $S$. pungens.

Differences between $S$. pungens and $S$. imperati (Busk) are explained above (see remarks for S. imperati). 
Schizoretepora pungens and S. aviculifera differ mainly on:

- shape and position of adventitious frontal avicularia: two types oval (Fig. 9F) and triangular, located and directed variably in $S$. pungens; only triangular, typically proximo-lateral to orifice and directed disto-laterally in S. aviculifera (Fig. 7E)

- shape and frequency of abfrontal avicularia, with two different shapes in S. pungens, triangular (always scarce and located at base of fenestrae) and oval, often numerous and scattered across kenozooids (Fig. 10E-F); only triangular but often very numerous in S. aviculifera (Fig. 7G)

- frontal surface, smooth or slightly rugose in S. pungens (Figs 9C, 10C), and clearly nodular in S. aviculifera (Fig. 7E)

- number of areolae larger in S. aviculifera (Fig. 7E): 6-8 (commonly 5), instead of 2-5 (commonly 3) in S. pungens (Figs 9F, 10C)

- lower peristome in S. aviculifera (Fig. 7B) than in S. pungens (Figs 9E, 10C)

Schizoretepora sp. nov.? (= S. imperati sensu O’Donoghue \& de Watteville 1939)

Fig. 11, Table 6

Non Retepora imperati - O’Donoghue \& de Watteville 1939: 25-26.

\section{Material examined}

EGYPT - 1 colony; Mediterranean Sea, Alexandria; coll. O'Donoghue; labelled Retepora imperati; NHMUK 1963.9.4.12.

\section{Description}

Colony erect, regularly fenestrate (reteporiform); frontal faces bearing autozooids, abfrontal faces consisting of sheets of kenozooids. Trabeculae with 2-6 longitudinal rows of autozooids arranged quincuncially. Fenestrae oval, 1-2 times as wide as trabeculae (Fig. 11A, E).

Autozooids longer than wide, convex, separated by distinct raised sutures. Frontal shield notably nodular, with 2-5 conspicuous areolae (Fig. 11C-D).

Primary orifice semi-elliptical, longer than wide, distal rim with 18 blunt, triangular denticles, proximal border with U-shaped sinus (wider than long) framed by two acute denticles that form a gutter on the proximal peristomial rim and flanked by smooth condyles, sloping towards the edges of the sinus (Fig. 11B).

Peristome relatively low, allowing most of the primary orifice features to be observed, with continuous proximal peristomial rim (Fig. 11B). Two oral spines, articulated, fragile and easily broken; only their bases remaining in older zooids (Fig. 11D). Although no club-like spines have been observed, there are differences in the diameter of their basis, supporting the possibility of their being present.

Giant avicularia on large cystid (with 2 pores) and very conspicuous; placed in different level of frontal and directed proximally or laterally; triangular, with straight borders and a hooked tip (Fig. 11D).

Ovicells were not observed.

Abfrontal convex and notably rugose, with large polygonal kenozooids separated by raised sutures and 1-3 pores (Fig. 11E). Abfrontal avicularia always triangular, with straight margins, hooked, variable in number but occasionally very numerous, of two different sizes, larger ones at basis of fenestrae; with slender crossbar, wide triangular lacuna and without columella (Fig. 11F). 


\section{Remarks}

This specimen seems closely related to $S$. imperati, with a similar general shape, a relatively low peristome, an orifice, spines and frontal as well as abfrontal avicularia. Nevertheless, there are subtle differences in the appearance: the surface is more nodular and the giant avicularia are somehow different, with straight or slightly convex margins and a more acute profile (VAL/VAW $>2$ ). The most remarkable differences, however, are in the biometric analysis (Fig. 3), with it being smaller than the rest of species studied.
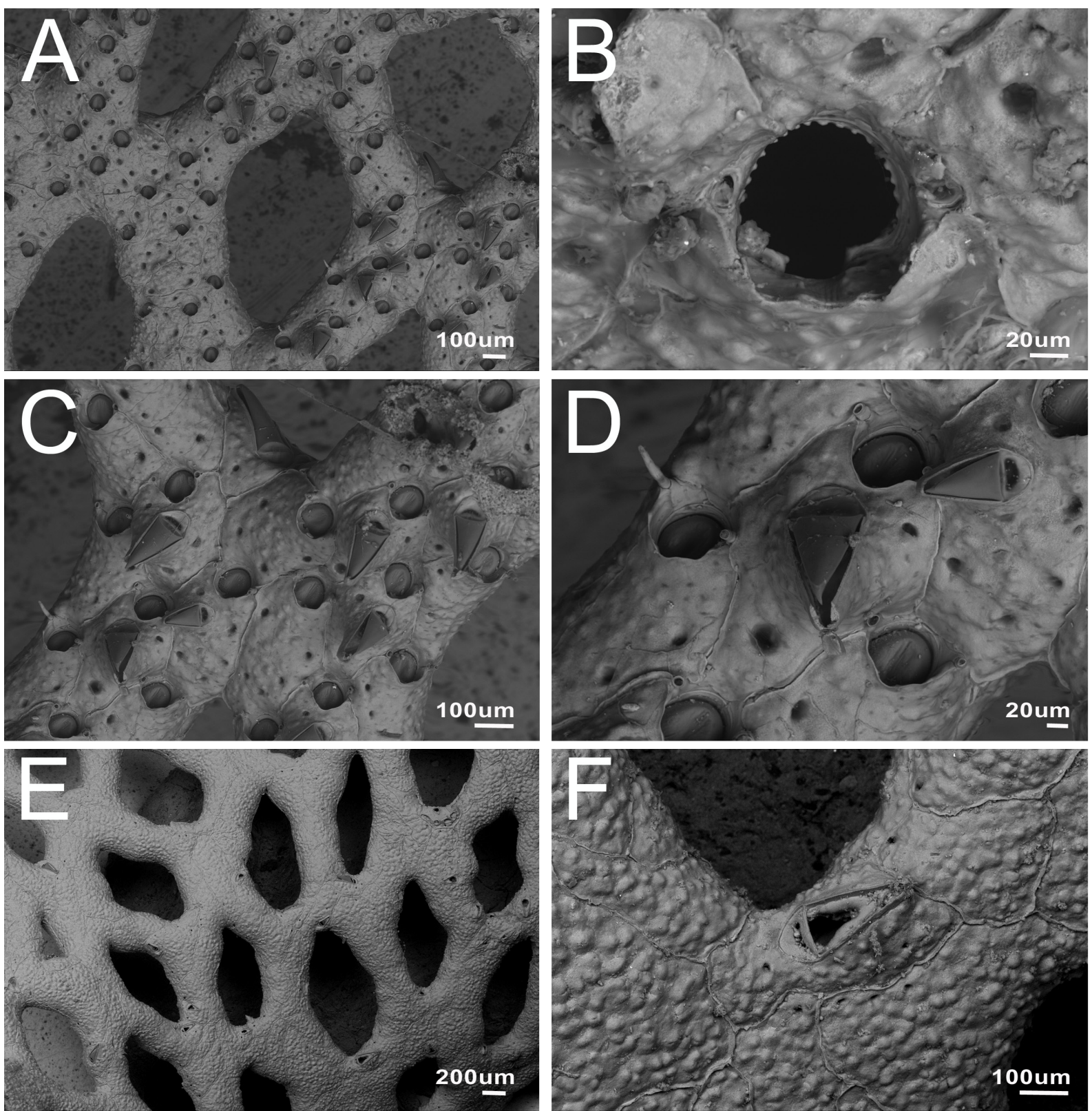

Fig. 11. Schizoretepora sp. nov. (= S. imperati sensu O'Donoghue \& de Watteville 1939), from Schizoretepora imperati, coll. O'Donoghue (NHMUK 1963.9.4.12). A. Colony view. B. Primary orifice showing distal denticles and proximal condyles. C. Autozooids with giant avicularia. D. Large vicarious avicularia on cystid. E. Abfrontal view. F. Detail of abfrontal avicularium and rugose surface. 
Table 6. Measurements of Schizoretepora sp. nov.? (= S. imperati sensu O’Donoghue \& de Watteville 1939).

\begin{tabular}{cccccc}
\hline & N & MEAN & SD & MIN & MAX \\
\hline FL & 9 & 1056 & 178 & 825 & 1335 \\
FW & 14 & 458 & 64 & 335 & 542 \\
TW & 24 & 493 & 87 & 369 & 686 \\
AzL & 30 & 357 & 35 & 301 & 450 \\
AzW & 24 & 258 & 36 & 200 & 350 \\
OL & 32 & 92 & 8 & 77 & 101 \\
OW & 41 & 82 & 6 & 69 & 92 \\
ApL & 15 & 92 & 6 & 80 & 102 \\
ApW & 10 & 89 & 7 & 79 & 98 \\
VAL & 19 & 183 & 26 & 134 & 227 \\
VAW & 24 & 74 & 16 & 44 & 99 \\
AbAL & 21 & 151 & 29 & 89 & 199 \\
AbAW & 20 & 56 & 13 & 38 & 84 \\
AbVL & 13 & 277 & 24 & 223 & 300 \\
AbVW & 11 & 95 & 12 & 80 & 115 \\
Ns & 20 & 2 & - & 2 & 3 \\
Np & 28 & 4 & 1 & 2 & 5 \\
Np_Ab & 30 & 2 & 1 & 1 & 3 \\
\hline
\end{tabular}

The rugose aspect of the frontal is reminiscent that of S. aviculifera, but it differs in the lack of frontal adventitious, almond-like avicularia.

O'Donoghue \& de Watteville (1939) identified this species as Retepora imperati, though expressing doubts about the number of existing species of Retepora at that time. They already pointed out the difficulties in identifying specimens of Reteporidae, taking into account the ontogenetic differences, age of colony and differential criteria used by each author.

Overall, the little existing material, the lack of an ovicell in the examined specimen, and the sole location (Alexandria; south-eastern corner of the Mediterranean) renders the status of this possible new species dubious.

\section{Discussion}

\section{The imperati-group problem}

The present study shows that all the species grouped as the imperati group (S. aviculifera, S. granulosa, $S$. imperati, S. longisetae and S. pungens) are in fact very similar, both in size and morphological features. Thus, the past puzzle and the existent taxonomical confusion are not only comprehensible but also justified. 


\section{Ontogenetic changes responsible}

Probably most of the muddle is due to the enormous ontogenetic variability of all members of the family Philoporidae. In any complete colony of lace coral, one can observe a striking transformation of the zooidal morphology, from young zooids located in apical margins to older ones placed in the basal parts. Young, just budded, zooids usually have a smooth frontal shield, exhibit numerous oral spines, present well-developed or large peristomes, and frequently lack other structures such as giant avicularia and ovicells (Figs 5C, 7C, E, 9A, C, E, 10A, G). When moving down to the basis of the colony, zooids begin to lose spines and peristomes, increasing calcification erodes edges and other structures (such as giant avicularia) and ovicells become frequent (Figs 5D, 7D, F, 9B, D, F, 10C, H). In consequence, it becomes difficult to decide on the diagnostic characters to distinguish the different species. Descriptions coming from the observation of just a part of these colonies, as often occurred in the original descriptions of species of the imperati group, can lead to disparate results and explain misidentifications. Another consequence is that their complete descriptions become exceptionally complex, requiring a comprehensive depiction of the different stages.

\section{Morphometric analysis}

The most commonly used characters for the determination of cheilostomatous bryozoans have shown no value in the present work due to the large similarity in shape and size of all the species from the imperati group studied. That is the case with the aperture (shape, condyles, sinus, denticles), spines (presence and number), giant avicularia and ovicell (shape). Finally, the most revealing character is the presence, shape and position of adventitious avicularia. Other more qualitative characters (e.g., rugosity of the frontal) that have shown to be helpful are difficult to classify and are also subject to ontogenetic changes. In summary, few characters showed intra-colonial stability and enough inter-colonial variability to discriminate between species.

Furthermore, the species making up the imperati group are very similar in size. Paired analysis of measurements did not allow clear metric limits to be set between species. Nevertheless, when considered in group, the multivariate analysis (Fig. 3) shows interesting results. On the one hand, it confirms the identity among all the Atlanto-Mediterranean records of $S$. imperati, S. longisetae and $S$. pungens, which appear close to each other, but far from the true $S$. imperati from the Cape Verde Islands (Eastern Atlantic). On the other hand, it also discriminates the group $S$. aviculifera-granulosa that is located between the former species and $S$. hassi, which is the largest one. Finally, it also supports the idea that S. imperati sensu O'Donoghue \& de Watteville 1939 from Alexandria in Egypt might be a different and undescribed species.

The large similarities observed in this complex of species suggest a recent speciation in the South Mediterranean-Atlantic area (Fig. 12).

\section{Historical revision}

The core of the problem of the imperati group begins with the original description of $S$. imperati itself. Busk (1884) gave this bizarre name to the material collected by the Challenger expedition at the Cape Verde Islands (Port Praia) by assuming that it belonged to Retepora cellulosa Linnaeus, 1758, a species abundant in the Mediterranean, but poorly described (lack of details in the drawings and misperception of characters) by previous authors such as Johnston; Ellis \& Solander and Imperato, to whom he dedicated the species.

Later, Waters (1925) provided more details on the description of $R$. imperati, based on Mediterranean material (from Oran). Waters (1925) pointed out that the peristome always hid the sinus observed by Busk (in fact Waters was 'redescribing' a different species, later described as $S$. longisetae). This first misidentification of $S$. imperati (Busk, 1884) led to subsequent confusion. 
The problem was further exacerbated by the contributions of Canu \& Bassler $(1925,1928,1930)$ that described four new species, three of them ascribed to the genus Schizellozoon (S. aviculiferum, $S$. granulosum and $S$. pungens) and Schizoretepora longisetae from the eastern Atlantic-south Mediterranean area. Apparently, when Canu \& Bassler (1925) described S. pungens they did not have their own material of $S$. imperati, and they based the differences of the new species on a comparison with the original description of Busk (1884). When in 1928 Canu \& Bassler again compared these two species, they had their own material of $S$. imperati from the Vanneau expedition (in the Morrocan Atlantic) and the material sent to them by Waters from Oran (Mediterranean). In that work, they insisted on the differences between $S$. imperati from Busk (1884) and the Mediterranean material as already highlighted by Waters (1925). Moreover, they stressed the similarity between their S. imperati and $S$. pungens. These precisions where adopted by more recent authors who synonymized S. pungens with S. imperati (Barroso 1935; Gautier 1962; d'Hondt 1978; Zabala 1986; Zabala \& Maluquer 1988; d'Hondt \& Ben Ismail 2008). However, Canu \& Bassler (1928) also described S. longisetae in the same work. The material used for the description of this species was sparse. When looking for differences compared to $S$. imperati and $S$. pungens, they pointed to the number of spines (4 instead of 2), longer autozooids and the presence of a small sinus on the proximal border of the peristome. As noted above in our description, the differences are simply ontogenetic, as they are characteristic of younger colonies of S. pungens, where all these traits are more conspicuous.

Schizoretepora aviculifera and S. granulosa, the other two species described by Canu \& Bassler (1930) from the Tunisian coast (Mediterranean), have generated less historical controversy because they were rarely cited, and most authors considered (equivocally) that they must be synonymized with $S$. imperati.

In summary, after this revision of the so-called imperati group (S. aviculifera, S. granulosa, S. imperati, S. longisetae and S. pungens) four different species remain:

1. The name $S$. imperati (Busk 1884) must be reserved for the eastern Atlantic material, which never bears small adventitious avicularia on the frontal shield.

2. Schizoretepora pungens regroups all the material formerly named $S$. imperati coming from the Mediterranean and nearby Atlantic waters, S. longisetae and S. pungens, which presents two types of adventitious avicularia (oval and almond-like) on the frontal shield.

3. Schizoretepora aviculifera gathers $S$. aviculifera and S. granulosa, characterized by having only one type of frontal adventitious avicularia (triangular) and numerous abfrontal triangular avicularia; this species is close to the recently described $S$. hassi (Harmelin et al. 2007), which differs in having a different colonial shape (non-fenestrate) and larger zooidal size.

4. Finally, S. imperati sensu O'Donoghue \& de Watteville 1939, from Alexandria seems to be a different species, only partially known (the ovicell has never been observed), whose description must wait for new material.

\section{Geographic distribution of Atlanto-Mediterranean species of Schizoretepora}

The new distribution derived from the present analysis attains a coherent geographical segregation of species of Schizoretepora (Fig. 12). Besides the four species mentioned above, another five species are found in the Atlanto-Mediterranean area. Schizoretepora calveti is a deep-water Atlantic species, well figured by Calvet (1931), but rarely found since its description (d'Hondt 1975); thus, new material is needed to ascertain its distributional range. Schizoretepora dentata was also found in deep Atlantic waters; however, its description was incomplete (ovicell unknown) and it has never been reported again. Furthermore, the original type (housed at MOM) is so badly damaged that it does not allow a 
significant redescription (Fig. 6). The status of this species will remain doubtful until new material is collected. Schizoretepora pungens and S. aviculifera are found along the Atlanto-Mediterranean coast of North Africa, from Morocco to Tunisia. Schizoretepora hassi and S. imperati sensu O'Donoghue \& de Watteville 1939 seem to be restricted to the limit of the south-eastern Mediterranean. Schizoretepora hassi was described recently and its similarity to S. aviculifera deserves further analysis. Finally, S. solanderia and S. serratimargo, which was just recently moved from the genus Schizotheca Hincks, 1877 by Harmelin et al. (2007), seem to be the only species inhabiting the European coasts of the Mediterranean.

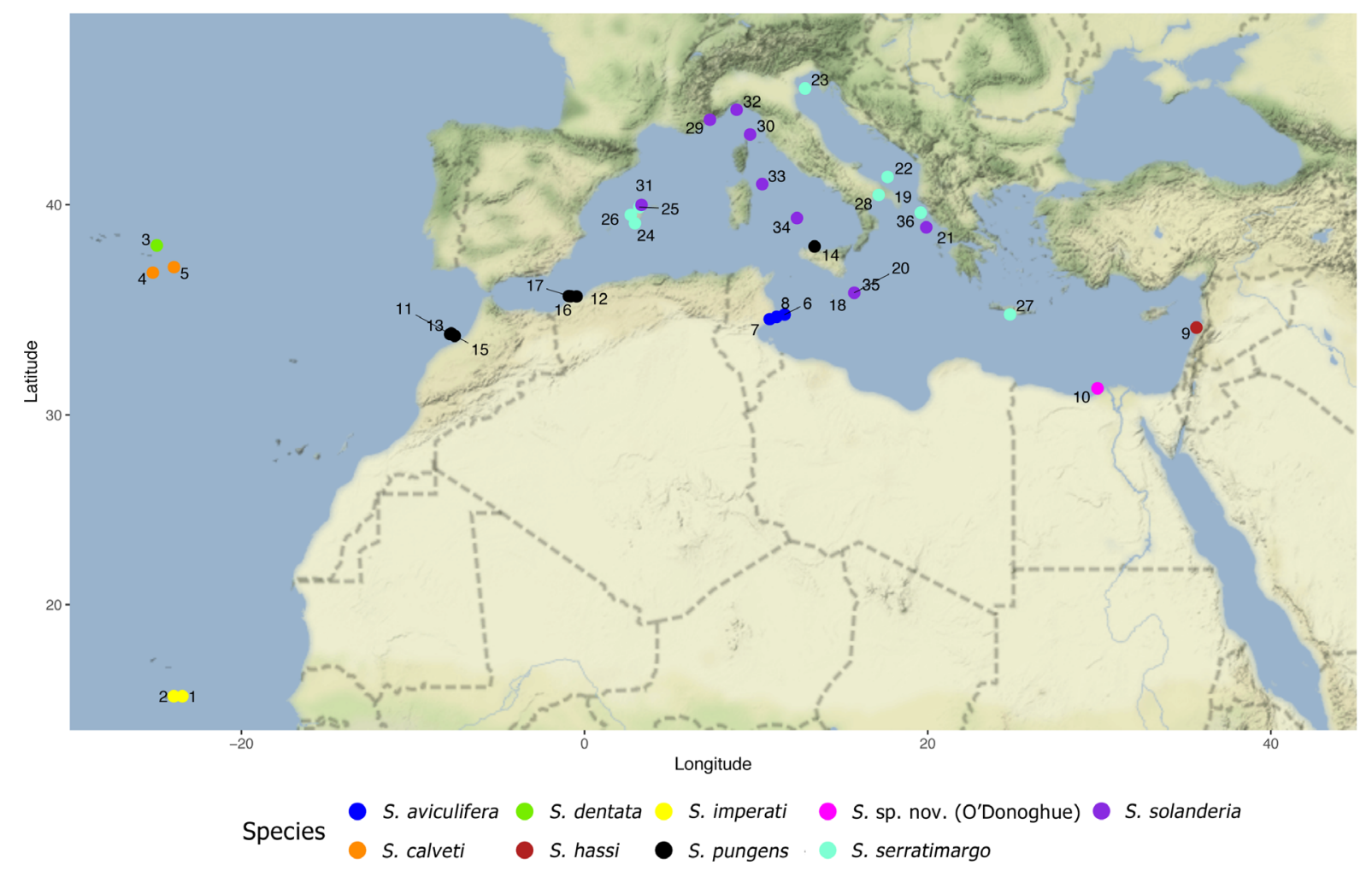

Fig. 12. Distribution of specimens studied: Schizoretepora imperati $(1=$ Retepora imperati, syntype (NHMUK 1934.2.16.23); 2 = Retepora imperati, syntype (NHMUK 1963.2.12.202)); Schizoretepora dentata (3 = Schizellozoon dentatum, holotype (MOM INV-22494-42 0559)); Schizoretepora calveti (4 = S. calveti, lectotype (MNHN-IB-2008-7565); 5 = Schizellozoon tesselatum Hincks var. nov. Calvet, 1931); Schizoretepora aviculifera (6 = Schizellozoon aviculiferum (MNHN-IB-2008-11126) and Schizellozoon longisetae (MNHN-IB-2008-11127); 7 = Schizellozoon granulosum, syntype (MNHNIB-2014-21); 8 = Schizellozoon aviculiferum, holotype (MNHN-IB-2014-24)); Schizoretepora hassi (9 = Harmelin et al. 2007); Schizoretepora sp. nov. (= S. imperati sensu O'Donoghue \& de Watteville 1939) $(10=$ S. imperati (NHMUK 1963.9.4.12)); Schizoretepora pungens $(11=$ S. longisetae, lectotype (MNHN-IB-2014-19); 12 = Retepora imperati (NHMUK 1911.10.1.813); $13=$ S. pungens, syntype (MNHN-IB-2014-20); $14=$ Retepora imperati (NHMUK 1911.10.1.1374); $15=$ Retepora imperati (MNHN-IB-2014-29); $16=$ Retepora imperati (MNHN-IB-2008-6052); $17=$ S. imperati $(\mathrm{MNHN}-$ IB-2008-11299); $18=$ S. imperati in Rosso et al. 2010); Schizoretepora serratimargo (19 = Hincks 1886; 20-23 = Rosso et al. 2010; 24-27 = Harmelin et al. 2007; 28 = Reverter-Gil \& Pulpeiro 2007); Schizoretepora solanderia (29 = Risso 1826; $30=$ Calvet 1902; $31=$ S. solanderia (MZB 2014-1471); 32-36 = Rosso et al. 2010). 


\section{Acknowledgements}

We are very grateful to Michèle Bruni (MOM) for lending us the type material of $S$. dentata and to all participants of Indemares cruises in the Menorca Channel during which the Schizoretepora material was collected. We are also thankful to J.-G. Harmelin for reading the draft and for the valuable suggestions and corrections provided to improve it. TM acknowledges support from the SYNTHESYS Project (grant no. FR-TAF-5655, http://www.synthesys.info/), financed by the European Community Research Infrastructure Action under the FP7 "Capacities Program", that allowed her to locate and study type and comparative material housed at the MNHN. TM is also grateful to Jerôme Mainguy (MNHN) for his assistance during her stay at the MNHM, and to Oscar Reverter-Gil (Universidad de Santiago de Compostela) for the help provided with the catalogues.

\section{References}

Barroso M.G. 1935. Notas sobre briozoos españoles. Boletin de la Real Sociedad Española de Historia Natural 35: 373-380.

Bock P. \& Gordon D. 2017. WoRMS Bryozoa: World List of Bryozoa (ver. 2017-10-08). In: Roskov Y., Abucay L., Orrell T., Nicolson D., Bailly N., Kirk P.M., Bourgoin T., DeWalt R.E., Decock W., De Wever A., Nieukerken E. van, Zarucchi J. \& Penev L. (eds) Species 2000 \& ITIS Catalogue of Life, $30^{\text {th }}$ October 2017. Available from www.catalogueoflife.org/col [accessed 17 Apr. 2019].

Busk G. 1884. Report on the Polyzoa collected by H.M.S. Challenger during the years 1873-1876. Part 1. The Cheilostomata. Report on the Scientific Results of the Voyage of the H.M.S. "Challenger", Zoology 10: 1-216.

Available from http://www.19thcenturyscience.org/HMSC/HMSC-Reports/Zool-30/README.htm [accessed 12 Apr. 2019].

Calvet L. 1902. Bryozoaires marins des côtes de Corse (recoltées par M. Caziot). Travaux de l'Institut de Zoologie de l'Université de Montpellier et de la Station zoologique de Cette 12: 1-52.

Calvet L. 1931. Bryozoaires provenant des campagnes scientifiques du Prince Albert Ir de Monaco. Résultats des Campagnes scientifiques accomplies sur son Yacht par Albert I ${ }^{e r}$, Prince souverain de Monaco 83: 1-152.

Canu F. \& Bassler R.S. 1917. A synopsis of American Early Tertiary Cheilostome Bryozoa. United States National Museum Bulletin 96: 1-87. https://doi.org/10.5479/si.03629236.96.1

Canu F. \& Bassler R.S. 1925. Les Bryozoaires du Maroc et de Mauritanie. Mémoires de la Société des Sciences naturelles du Maroc 10: 1-79.

Canu F. \& Bassler R.S. 1928. Les bryozoaires du Maroc et de Mauritanie, $2^{\text {ième }}$ Mémoire. Mémoires de la Société des Sciences naturelles du Maroc 18: 1-85.

Canu F. \& Bassler R.S. 1930. Bryozoaires marins de Tunisie. Annales de la Station océanographique de Salambô 5: 1-91.

Clarke K.R. \& Gorley R.N. 2006. PRIMER ver. 6: User Manual/Tutorial. PRIMER-E, Plymouth, UK.

d'Hondt J.-L. 1975. Bryozoaires Cténostomes et Cheilostomes (Cribrimorphes et Escharellidae exceptés) provenant des dragages de la campagne océanographique Biaçores du "Jean Charcot". Bulletin du Muséum national d'Histoire naturelle 299: 553-600.

d'Hondt J.-L. 1978. Les bryozoaires du Maroc et de Mauritanie (troisième mémoire, pour faire suite aux publications de F. Canu et R.S. Bassler). Cahiers de Biologie marine 19: 447-458.

d'Hondt J.-L. \& Ben Ismail D. 2008. Bryozoaires des côtes algériennes. Compléments aux bryozoaires de Tunisie. Bulletin de la Société zoologique de France 133 (1-3): 55-71. 
Gautier Y.V. 1962. Recherches écologiques sur les bryozoaires cheilostomes en Mediterranée occidentale. Recueil des Travaux de la Station marine d'Endoume 38 (24): 1-434.

Gregory J.W. 1893. On the British Palaeogene Bryozoa. Transactions of the Zoological Society of London 13: 219-279. https://doi.org/10.1111/j.1096-3642.1893.tb00050.x

Harmelin J.-G., Bitar G. \& Zibrowius H. 2007. Schizoretepora hassi sp. nov. (Bryozoa: Phidoloporidae) from Lebanon (Eastern Mediterranean) and reappraisal of Schizotheca serratimargo (Hincks, 1886). Cahiers de Biologie marine 48 (2): 179-186. https://doi.org/10.21411/CBM.A.42C2A0A, see also http://www.bryozoa.net/ [accessed Feb. 2019].

Hincks T. 1886. The Polyzoa of the Adriatic: a supplement to Prof. Heller's "Die Bryozoen des adriatischen Meeres", 1867. Annals and Magazine of Natural History, Series 5 17: 254-271. https://doi.org/10.1080/00222938609460142

López de la Cuadra C.-M. \& García Gómez J.-C. 2001. New and little-known ascophoran bryozoans from the Western Mediterranean, collected by the 'Fauna Iberica' expeditions. Journal of Natural History 35 (11): 1717-1732. https://doi.org/10.1080/002229301317092414

O'Donoghue C.H. \& de Watteville D. 1939. Bryozoa. Report No. 20. The fishery grounds near Alexandria. Fouad I Institute of Hydrobiology \& Fisheries 34: 1-58.

Reverter Gil O. \& Fernández-Pulpeiro E. 2007. Species of genus Schizotheca Hincks (Bryozoa, Cheilostomata) described in the Atlantic-Mediterranean region, with notes on some species of Parasmittina Osburn. Journal of Natural History 41 (29-32): 1929-1953.

https://doi.org/10.1080/00222930701515520

Risso A. 1826. Histoire naturelle des principales productions de l'Europe méridionale et particulièrement de celles des environs de Nice et des Alpes maritimes: tome cinquième. F.-G. Levrault, Paris. Available from http://www.biodiversitylibrary.org/bibliography/58984 [accessed 10 Apr. 2019].

Rosso A. 2003. Bryozoan diversity in the Mediterranean Sea. Biogeographia 24: 227-250. https://doi.org/10.21426/B6110120

Rosso A., Chimenz C. \& Balduzzi A. 2010. Bryozoa. Biologia Marina Mediterranea 17 (1): 589-615.

Rosso A. \& Di Martino E. 2016. Bryozoan diversity in the Mediterranean Sea: an update. Mediterranean Marine Science 17 (2): 567-607. https://doi.org/10.12681/mms. 1706

Schneider C.A., Rasband W.S. \& Eliceiri K.W. 2012. NIH Image to ImageJ: 25 years of image analysis. Nature Methods 9 (7): 671-675. https://doi.org/10.1038/nmeth.2089

Sokolover N., Taylor P. \& Ilan M. 2016. Bryozoa from the Mediterranean coast of Israel. Mediterranean Marine Science 17 (2): 440-458. https://doi.org/10.12681/mms.1390

Waters A.W. 1895. On Mediterranean and New Zealand Reteporae and fenestrate Bryozoa. Journal of the Linnean Society, Zoology 25: 255-271. https://doi.org/10.1111/j.1096-3642.1895.tb00389.x

Waters A.W. 1925. Some cheilostomatous Bryozoa from Oran (Algiers). Annals and Magazine of Natural History (9) 15: 651-661. https://doi.org/10.1080/00222932508633260

WORMS. Available from http://www.marinespecies.org/ [accessed Feb. 2019].

Zabala M. 1986. Fauna dels Briozous dels Països Catalans. Institut d'Estudis Catalans, Arxius de la Secció de Ciéncies, Barcelona 84: 1-836.

Zabala M. \& Maluquer P. 1988. Illustrated keys for the classification of Mediterranean Bryozoa. Treballs del Museu de Zoologia, Barcelona 4: 1-294. Available from

http://www.raco.cat/index.php/TreballsMZ/article/view/108369/168548 [accessed 24 Apr. 2019]. 
Manuscript received: 17 May 2018

Manuscript accepted: 10 April 2019

Published on: 9 July 2019

Topic editor: Rudy Jocqué

Desk editor: Kristiaan Hoedemakers

Printed versions of all papers are also deposited in the libraries of the institutes that are members of the EJT consortium: Muséum national d'Histoire naturelle, Paris, France; Meise Botanic Garden, Belgium; Royal Museum for Central Africa, Tervuren, Belgium; Royal Belgian Institute of Natural Sciences, Brussels, Belgium; Natural History Museum of Denmark, Copenhagen, Denmark; Naturalis Biodiversity Center, Leiden, the Netherlands; Museo Nacional de Ciencias Naturales-CSIC, Madrid, Spain; Real Jardín Botánico de Madrid CSIC, Spain; Zoological Research Museum Alexander Koenig, Bonn, Germany; National Museum, Prague, Czech Republic. 